\title{
A model of the methane cycle, permafrost, and hydrology of the Siberian continental margin
}

\author{
D. Archer \\ University of Chicago, Department of the Geophysical Sciences, Chicago, USA \\ Correspondence to: D. Archer (d-archer@uchicago.edu)
}

Received: 15 April 2014 - Published in Biogeosciences Discuss.: 3 June 2014

Revised: 26 March 2015 - Accepted: 13 April 2015 - Published: 21 May 2015

\begin{abstract}
A two-dimensional model of a sediment column, with Darcy fluid flow, biological and thermal methane production, and permafrost and methane hydrate formation, is subjected to glacial-interglacial cycles in sea level, alternately exposing the continental shelf to the cold atmosphere during glacial times and immersing it in the ocean in interglacial times. The glacial cycles are followed by a "long-tail" $100 \mathrm{kyr}$ warming due to fossil fuel combustion.

The salinity of the sediment column in the interior of the shelf can be decreased by hydrological forcing to depths well below sea level when the sediment is exposed to the atmosphere. There is no analogous advective seawaterinjecting mechanism upon resubmergence, only slower diffusive mechanisms. This hydrological ratchet is consistent with the existence of freshwater beneath the sea floor on continental shelves around the world, left over from the last glacial period.

The salt content of the sediment column affects the relative proportions of the solid and fluid $\mathrm{H}_{2} \mathrm{O}$-containing phases, but in the permafrost zone the salinity in the pore fluid brine is a function of temperature only, controlled by equilibrium with ice. Ice can tolerate a higher salinity in the pore fluid than methane hydrate can at low pressure and temperature, excluding methane hydrate from thermodynamic stability in the permafrost zone. The implication is that any methane hydrate existing today will be insulated from anthropogenic climate change by hundreds of meters of sediment, resulting in a response time of thousands of years.

The strongest impact of the glacial-interglacial cycles on the atmospheric methane flux is due to bubbles dissolving in the ocean when sea level is high. When sea level is low and the sediment surface is exposed to the atmosphere, the atmospheric flux is sensitive to whether permafrost inhibits bub-
\end{abstract}

ble migration in the model. If it does, the atmospheric flux is highest during the glaciating, sea level regression (soilfreezing) part of the cycle rather than during deglacial transgression (warming and thawing).

The atmospheric flux response to a warming climate is small, relative to the rest of the methane sources to the atmosphere in the global budget, because of the ongoing flooding of the continental shelf. The increased methane flux due to ocean warming could be completely counteracted by a sea level rise of tens of meters on millennial timescales due to the loss of ice sheets, decreasing the efficiency of bubble transit through the water column. The model results give no indication of a mechanism by which methane emissions from the Siberian continental shelf could have a significant impact on the near-term evolution of Earth's climate, but on millennial timescales the release of carbon from hydrate and permafrost could contribute significantly to the fossil fuel carbon burden in the atmosphere-ocean-terrestrial carbon cycle.

\section{Introduction}

\subsection{The Siberian continental shelf system}

The Siberian Arctic continental shelf has been the focus of attention from scientists and the public at large for its potential to release methane, a greenhouse gas, in response to climate warming, a potential amplifying positive feedback to climate change (Shakhova, 2010; Westbrook et al., 2009). The goal of this paper is to simulate the geophysical and carbon cycle dynamics of the Siberian continental margin within the context of a basin- and geologic-timescale mechanistic model of the coastal margin carbon cycle called SpongeBOB 
(Beneath Ocean Biosphere; Archer et al., 2012). An initial condition for the glacial cycle simulations was generated by spinning the model up at low resolution over 62 million simulated years. Then the model is driven, at higher resolution, by cyclic changes in sea level and air temperature resulting from glacial cycles, to simulate the impact of the hydrological pressure head and permafrost formation on the fluid flow and methane cycle on the shelf. Finally, a 100000 -year interglacial interval in the simulation is subjected to anthropogenic warming of the overlying water and potential $60 \mathrm{~m}$ changes in sea level. Sensitivity studies are presented for the biogenic and thermogenic methane production rates, initial salinity, geothermal temperature gradient, rates of hydrological flow, and permafrost impact on gas mobility.

\subsubsection{Permafrost}

One component of the simulation is a wedge of frozen sediment (permafrost) submerged beneath the ocean on the continental shelf of Siberia, left behind from the Last Glacial Maximum, when the shelves were exposed to the frigid atmosphere by lowered sea level (Romanovskii and Hubberten, 2001). The ice is thought to provide a seal to the upward migration of methane gas (Shakhova et al., 2009), especially where ancient fresh groundwater flow produced a layer of very high saturation ice infill, a formation called the Ice Complex in Siberia (Romanovskii et al., 2000), although there are high ice saturations found in the Alaskan Arctic as well (Zimov et al., 2006).

With inundation by the natural sea level rise over more than the last 10000 years, the permafrost is transiently melting, although the time constant for this is generally long enough for significant frozen volume to remain, especially in shallower waters which were flooded more recently (Khvorostyanov et al., 2008a; Nicolsky and Shakhova, 2010; Romanovskii and Hubberten, 2001; Romanovskii et al., 2004; Shakhova et al., 2009; Taylor et al., 1996). Even overlying water at the freezing temperature can provoke subsurface melting by providing a warmer boundary condition against which geothermal heat establishes the subsurface temperature profile, but with climate warming, the waters could surpass the freezing temperature, allowing heat to flow from above as well as below (Khvorostyanov et al., 2008b).

Elevated methane concentrations have been measured in the water column over the Siberian shelf, even in areas of shallow water where the permafrost should still be strongly intact (Shakhova, 2010; Shakhova et al., 2005). Chemical and isotopic signatures of hydrocarbons adsorbed onto surface sediments indicate a thermal origin (Cramer and Franke, 2005), suggesting that the methane is produced many kilometers deep in the sediment column. The apparent ability of this methane to transverse the barrier of the Ice Complex has been attributed to hypothesized openings in the ice (called "taliks"), resulting from lakes or rivers on the exposed shelf, or to geologic faults (Nicolsky and Shakhova, 2010; Romanovskii et al., 2004; Shakhova et al., 2009).

\subsubsection{Salt}

Dissolved salt in the pore waters can impact the timing of thawing permafrost (Nicolsky and Shakhova, 2010; Shakhova et al., 2009). When sea level drops and exposes the top of the sediment column to the atmosphere and freshwater, the salinity of the subsurface pore waters can be flushed out by hydrological groundwater flow, driven by the pressure head from the elevated terrestrial water table above sea level. The boundary between fresh and salty pore water tends to intersect the sediment surface at the water's edge (Moore et al., 2011). From there, the boundary tends to dip landward, to a depth of approximately $40 \mathrm{~m}$ below sea level for every $1 \mathrm{~m}$ of elevation of the table water. The ratio of water table elevation to freshwater lens depth is driven by the relative densities of fresh- and salt water, as the fluid seeks an isostatic balance in which the freshwater displaces an equal mass of salt water (Verrjuit, 1968).

The SpongeBOB model has been modified to simulate the processes responsible for these observations. We do not attempt to simulate a detailed outcropping history over a 62million-year spinup time of the sediment column but rather demonstrate the general process by subjecting the nearly complete sediment column to a one-time sea level lowering, exposing the continental shelf to groundwater forcing (see Sect. A4). After a few million years, the sediment column subsides, due to compaction and the absence of sediment deposition, resulting in a sediment column that has been considerably freshened by the atmospheric exposure. This freshening persists in the model for millions of years because there is no corresponding "salt-water pump" during high sea level stands. This behavior is consistent with the discovery of vast nearly fresh aquifers in currently submerged continental shelf regions around the world (Post et al., 2013), left over from groundwater forcing during the Last Glacial Maximum.

\subsubsection{Carbon}

Another component of the simulation is the Yedoma, deposits of wind-blown dust and organic carbon that accumulated on the coastal plains of exposed continental shelves during glacial times (Zimov et al., 2006). The deposits contain a substantial fraction of organic carbon, consisting of grass roots and remains preserved by the freezing conditions. When they thaw, they begin to release $\mathrm{CO}_{2}$ and methane to the atmosphere (Dutta et al., 2006; Schuur et al., 2008; Zimov et al., 2006). Oxidation of the carbon can give off enough heat to accelerate the melting driven by primary climate forcing (Khvorostyanov et al., 2008b). 


\subsection{Models of methane hydrate in the permafrost zone}

The dynamics of the permafrost layer, and its present state, have been extensively modeled within the context of detailed maps of the crust and sediment structure (Gavrilov et al., 2003; Nicolsky and Shakhova, 2010; Nicolsky et al., 2012; Romanovskii and Hubberten, 2001; Romanovskii et al., 2005). Methane hydrate modeling has been done in the Arctic and applied to the Siberian continental slope (Reagan, 2008; Reagan and Moridis, 2009; Reagan et al., 2011), but only one calculation has been done in the context of permafrost formation (Romanovskii et al., 2005) as found on the shelf. Romanovski (2005) modeled the extent of the methane hydrate stability zone through glacial cycles but based the calculations on marine salinity values when calculating the stability of hydrate. I will argue that in sub-freezing conditions (in the permafrost zone) the only water available for hydrate formation will be in a saline brine that would be in equilibrium with ice at the local temperature. This formulation restricts hydrate stability from the permafrost zone to a greater depth below the sea floor than if the salinity was unaffected by the formation of ice.

\subsection{Outline of this work}

The model description in Sect. 2 begins with a description of the previously published aspects of the SpongeBOB model as it is applied to the Siberian margin (Sect. 2.1). New developments in the code include pressure-head-driven groundwater flow (Sect. 2.2), permafrost formation and its impacts on the thermodynamics of ice and hydrate (Sect. 2.3), and the calculation of the methane flux to the atmosphere (Sect. 2.4). The procedure for generating the initial-condition sediment column for the glacial-interglacial cycles (Sect. 2.5) is presented along with a description of the forcings imposed to generate the glacial-interglacial cycles (Sect. 2.6) and the subsequent Anthropocene (Sect. 2.7). The formulation and rationale for the sensitivity studies is given in Sect. 2.8.

The Results section (Sect. 3) includes a discussion of the model behavior through the glacial-interglacial cycles (Sect. 3.1) and in response to anthropogenic global warming scenarios (Sect. 3.2). A summary of model sensitivity study results is given in Sect. 3.3 and comparison with field observations in Sect. 3.4.

The Discussion section (Sect. 4) includes the model limitations and critical issues for future development (Sect. 4.1), followed by the robust features of the model simulations (Sect. 4.2).

\section{Model description}

\subsection{SpongeBOB application to the Siberian continental margin}

SpongeBOB is a two-dimensional basin spatial-scale and geological-timescale model for the methane cycle in continental-margin sediments. The model, configured for a passive margin basin, was described by Archer et al. (2012) and applied to the Atlantic coast of the United States. The bottom boundary is bedrock, and accumulation timescales are millions of years, as sediment is introduced as coastal riverine material and settles on the sea floor. Isostatic adjustment and crustal subsidence make room for the accumulation of $5-10 \mathrm{~km}$ of sediment, which progrades seaward in sigmoidal packages, driven by a maximum sediment accumulation rate just off the shelf break.

Here the model framework is used as a representation of the continental shelf of Siberia, although the tectonic and depositional histories of the region are heavily impacted by vertical tectonic motions not represented in the model. The crust underlying the continental shelf area has been alternately rising and subsiding in blocks called horsts and grabens (Nicolsky et al., 2012). The sediment cover on the grabens is thick, much thicker than it is in the horsts, and thick enough for thermal methane production. The thickness of the sediment cover in the model ranges from 5 to $10 \mathrm{~km}$ throughout the domain, reminiscent of the grabens (subsiding blocks) because thermogenic methane is an essential part of the simulations.

The model maintains a concentration of particulate organic carbon with which it predicts rates of methanogenesis. However, because the depositional histories and organiccarbon concentrations in the Siberian continental margin are not well constrained, the rates of biological and thermal methane production predicted by the model are unreliable predictors of reality. For this reason, methanogenesis rates in the model are scaled arbitrarily as tunable model inputs. The depth distributions of the sources depend mostly on temperature, an easier variable to predict than organic-carbon degradation activity.

\subsection{New model development: groundwater hydrology}

\subsubsection{Pressure head}

When the sediment column is exposed to the atmosphere, the pressure field from the variable elevation of the water table (the pressure head) begins to affect the fluid flow. The pressure head for a fluid particle at the depth of the water table varies in the following way:

$P_{\text {head }}(z)=g \int_{z}^{z_{\mathrm{wt}}} \rho_{\text {seawater }} \mathrm{d} z$

where $z_{\mathrm{wt}}$ is the elevation of the water table, which affects the pressure throughout the fluid column, and the integral of 
the fluid density allows the pressure at depth to be affected by the salinity and temperature of the water above. The depth of the water table is a prognostic variable in the model. In these simulations, however, the water table remains very close to the sediment surface, as unsaturated soil produced by subsurface flow is quickly replenished by hydrological recharge.

\subsubsection{Pore fluid flow}

The pressure head acts in concert with the excess pressure $\mathrm{P}_{\text {excess }}$, as defined by Archer et al. (2012), to drive horizontal Darcy flow through the sediment. The value of $P_{\text {excess }}$ is determined from the porosity and sediment load of the sediment in each grid box. An assumed sediment rheology is used to calculate the load-bearing capacity of the solid matrix within a given grid cell. $P_{\text {excess }}$ is calculated by assuming that the load of the solid phase overlying the grid cell that is not carried by the solid matrix must be carried by the $P_{\text {excess }}$ in the fluid phase.

The horizontal flow is

$$
\begin{aligned}
& u_{\text {Darcy }, i \rightarrow i+1}= \\
& \frac{k_{h, i}+k_{h, i+1}}{2 \mu} \frac{\left(P_{\text {excess }, i}-P_{\text {excess }, i+1}\right)+\left(P_{\text {head }, i}-P_{\text {head }, i+1}\right)}{\left(\Delta x_{i}+\Delta x_{i+1}\right) / 2},
\end{aligned}
$$

while the vertical flow in the model is driven only by compaction pressure

$w_{\text {Darcy }, j \rightarrow j+1}=\frac{k_{v, j}}{\mu} \frac{P_{\text {excess }, j}-P_{\text {excess }, j+1}}{\left(\Delta z_{j}+\Delta z_{j+1}\right) / 2}$,

where $k_{h, i}$ is the horizontal permeability at horizontal cell index $j, k_{v, j}$ is vertical permeability at vertical index $j, \mu$ is the viscosity, and $\Delta x$ and $\Delta z$ are cell dimensions. Notes on numerical issues are given in the Supplement.

\subsubsection{Canyons}

The model as described so far represents a laterally homogeneous slab, a poor approximation of hydrology above sea level because of the formation of canyons and river networks in a real drained plateau. The depth of the water table in a river canyon is depressed, relative to the surroundings, to the depth of the canyon. The water table is higher in between the canyons because of recharge, and the difference in head drives lateral flow, the canyons acting to drain the sediment column.

The model formulation has been altered to represent these mechanics in a simplified way. Rather than expand the model into the full third dimension, the two-dimensional field of the model is held to represent the sediment column at a hypothetical ridge crest, as altered by an adjacent canyon. The canyon elevation is represented by $z_{\text {canyon }}$ and its width by a scale $\Delta y_{\text {canyon }}$. A cross-column flow velocity $v_{\text {Darcy, } \mathrm{j}}$ is calculated as

$v_{\text {Darcy }, j}=\frac{k_{h, j}}{\mu} \frac{\left(P_{\text {head, canyon }}-P_{\text {head }}\right)}{\Delta y_{\text {canyon }}}$, where $P_{\text {head, canyon }}$ is the pressure head as a function of depth in the hypothetical canyon, calculated assuming that the water table outcrops at $z_{\text {canyon }}$ and that the temperatures in the sediment column have adjusted to the formation of the canyon such that the near-surface geothermal gradient is the same between the hypothetical canyon and the bulk sediment column. The lateral "drainage" flow $\left(v_{\text {Darcy }, \mathrm{j}}\right)$ drives vertical velocities by continuity.

The horizontal distance scale $\Delta y_{\text {canyon }}$ is somewhat arbitrary and difficult to constrain, given that, in the reality of river networks, the distance to the nearest canyon from any point in the domain is likely to be a function of altitude, distance from the coast, and time. Another poorly resolved factor is the depth of the canyon. In reality, canyons cut into a plateau following a dynamic that erosion is proportional to slope, stopping at sea level. As a simplification the model is set to hold the canyon depth at current sea level throughout the simulation.

In the real fractal geometry of canyons, the spacing between canyons across a plain is similar to the width of the plain (length of the canyons), so the base simulation assumes a canyon width of $100 \mathrm{~km}$, based on the width scale of the continental shelf of more than $100 \mathrm{~km}$.

\subsection{Permafrost}

\subsubsection{Thermodynamics of ice and hydrate}

The ice model is based on an assumption of thermodynamic equilibrium, in which the heat content of the cell is distributed between the pure ice, hydrate, and brine phases, while the salt content is restricted to the brine. Notes on numerical implementation are given in the Supplement Text S2.

In the permafrost zone where ice is present, the salinity of the brine creates an ice freezing point depression that matches the local temperature. This equilibrium salinity is higher than methane hydrate can tolerate, excluding hydrate from thermodynamic stability. For a more detailed examination of the role of the brine salinity in determining the relative stabilities of ice and hydrate, see the Supplement Text S3.

\subsubsection{Other impacts}

Permafrost formation has several impacts on the methane cycle in the model. Biogenic methanogenesis is assumed to be stopped in the ice fraction of a grid cell (which approaches unity but never reaches it in the model, due to the exclusion of salt into brine). Bubble transport in the model balances bubble production, driven by a small and not very well constrained standing bubble concentration within the pore space. It is generally assumed (Shakhova et al., 2010b) that permafrost inhibits gas transport through the sediment column, both based on sediment column carbon and hydrogen budgets (Hunt, 1995) and on the tight seal provided by the Ice Complex. The seal provided to Arctic lakes, which can drain 
overnight if the seal is breached, also lends credence to this idea. In the model, this effect was simulated by stopping gas transport completely when a grid cell exceeds $50 \%$ ice fraction (with sensitivity runs assuming 10, 30, 70, and 90\%).

\subsection{Atmospheric methane fluxes}

Bubbles emerging from the sediment column into the water column of the ocean may dissolve in the water column, or they may reach the sea surface, a direct methane flux to the atmosphere (Westbrook et al., 2009). In the model, bubble dissolution in the water column is assumed to attenuate the bubble flux according to the water depth, with an $e$-folding attenuation scale of $30 \mathrm{~m}$ (Gentz et al., 2014; Portnov et al., 2013; Westbrook et al., 2009). In reality, a low-flux gas seep, producing small bubbles, will probably not reach as far into the water column as a $30 \mathrm{~m}$ scale height, while a faster seep can reach further. Methane dissolved in the water column, in reality, may survive oxidation (time constant of about a year) and degas to the atmosphere, but this possibility is not included in the model. For land grid points (exposed to the atmosphere by lowered sea level), any upward bubble flux at the sediment surface is assumed to be released $100 \%$ to the atmosphere. The model neglects methane oxidation in soils, as well as many other terrestrial processes, such as thaw bulbs beneath bodies of water (Walter et al., 2006) and the seasonal cycle of melting and thawing in the surface active layer (see the discussion in Sect. 4.1).

\subsection{Initial condition}

\subsubsection{Rationale for spinup}

The point of the spinup phase is to generate an initial condition for the glacial cycle simulations. The more usual approach in modeling hydrates is to start with an ad hoc initial condition (Reagan, 2008; Reagan and Moridis, 2009; Reagan et al., 2011). For SpongeBOB the model state at any time is the result of the time history of sedimentation, which is driven by the time-evolving depth of the sea floor and interacts with isostatic adjustment of the crust. The simplest way to generate an initial condition in the model without a startup transient is to spin the model up from bedrock. The duration of the spinup phase is 62 million years, roughly consistent with the timescale since the opening of the Laptev Rift. The first $60 \mathrm{Myr}$ used a relatively coarse resolution, as shown in Fig. 1a. For the glacial-interglacial experiments, the initial condition was interpolated to a higher-resolution grid in the vertical, as shown in Fig. 1 b.

\subsubsection{Sediment column salt content}

When sea level drops such that the surface of the sediment column outcrops to the atmosphere, the pore fluid becomes subject to the pressure head driving it seaward and to freshwater recharge from precipitation. The pressure head forcing
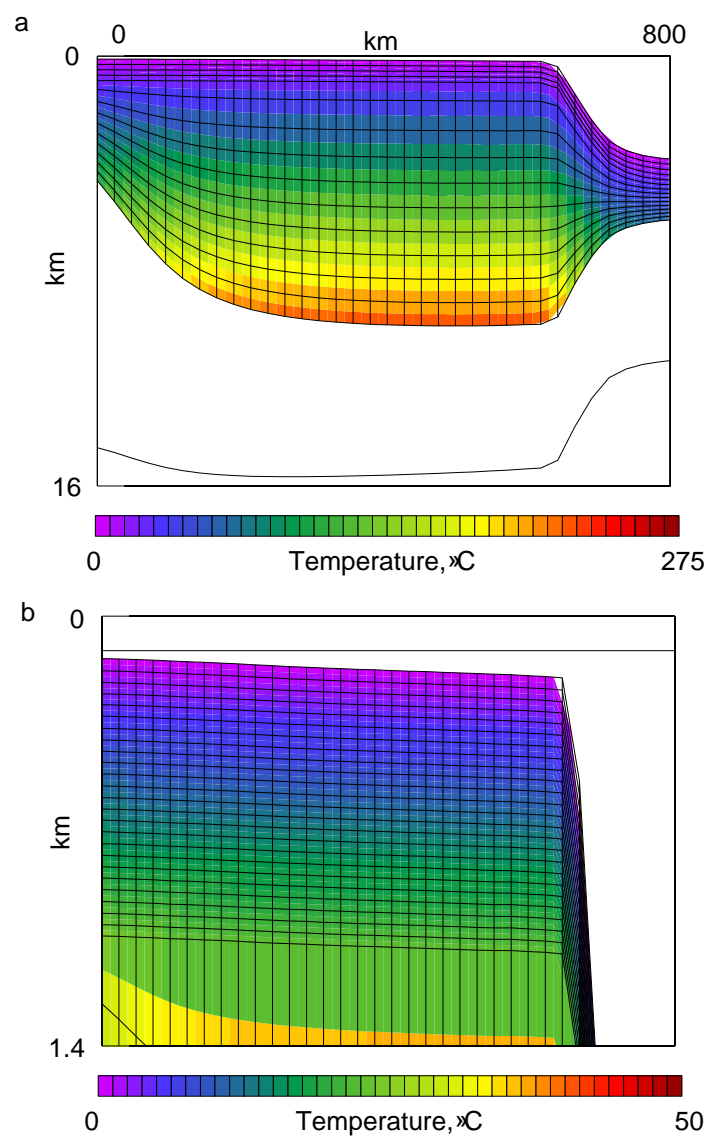

Figure 1. Domain of the model as applied to the Laptev Sea continental shelf and slope. This is the result of 62 million years of sediment accumulation on the crust, isostatic subsidence, pore fluid flow, and thermal diffusion, used as the initial condition for glacialinterglacial cycle and climate change simulations. Color indicates temperature. (a) Full view. Black line shows the bottom of the crust, which grades smoothly from continental on the left into ocean crust through most of the domain on the right. (b) Close-up showing increased model resolution in the upper kilometer of the sediment column.

and the buoyancy of the sediment fluid column combine to create a mechanism to excavate salinity from the upper sediment column to depths well below sea level. The salinity of the sediment column tends to be ratcheted down by exposure to the atmosphere because there is no comparable advective pump for the reinvasion of seawater when sea level rises.

A "prefreshened" sediment column was constructed by dropping sea level by $120 \mathrm{~m}$ and holding it there for millions of years. The sediment column subsides back into the ocean over a few million years, but the fresh imprint of the hydrological flow persists for millions of years (Fig. 2a and Text S4). If the sediment surface never outcrops, the pore salinities remain nearly uniform and marine (Fig. 2b). Particulate organic carbon (POC) concentrations are highest just off the shelf break (Fig. 3) because this is where most of the 
a

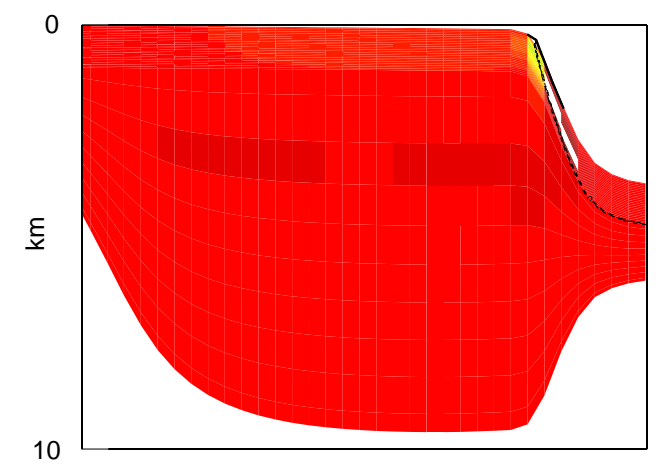

b

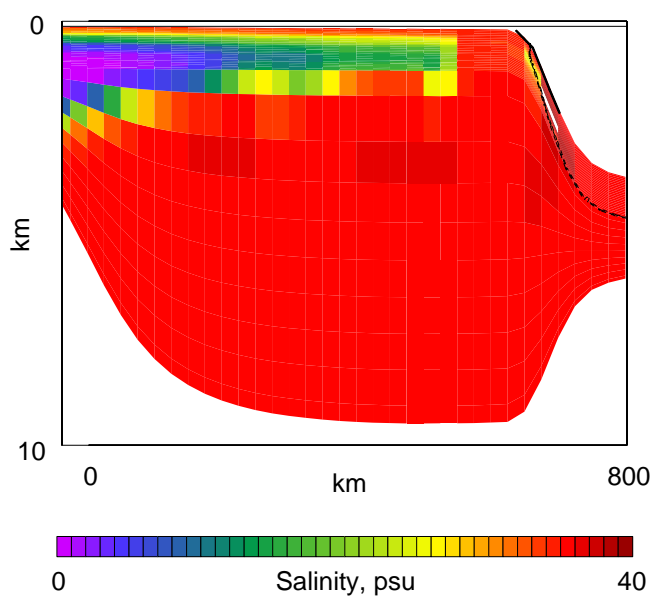

Figure 2. Pore water salinity. (a) The fully marine case, in which the sediment column has always been submerged underneath a timeinvariant sea level. (b) Result of sediment column freshening by hydrological groundwater flow, driven by the pressure head resulting from a water table higher than sea level. A movie of the transition from marine to freshened (the origin of $\mathbf{b}$ ) can be seen at http: //geosci.uchicago.edu/ archer/spongebob_arctic/fig2.movie.gif.

sediment is deposited, and because the sedimentary material is richest in POC in shallow ocean water depths (Archer et al., 2012). Methane concentration (Fig. 4a) closely mirrors the solubility of dissolved methane, resulting in nearsaturation concentrations through most of the model domain (Fig. 4b). The prefreshened (Fr) versus marine (Mr) initial conditions are taken as end member salinity sensitivity runs (see Table 1).

\subsection{Glacial cycle forcing}

Beginning from an entirely submerged initial condition, the model is subjected to $100 \mathrm{kyr}$ sawtooth cycles of sea level ranging between -120 to $+20 \mathrm{~m}$ from the initial sea level (starting at -120 for prefreshened and 0 for pure marine; Fig. 5a). The model forcing scenarios are summarized, with their abbrevations, in Table 1.

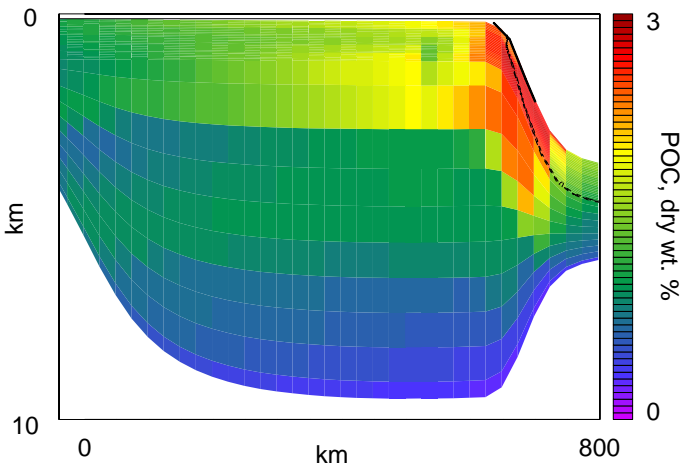

Figure 3. Particulate organic carbon (POC) concentration. Highest values are found in the sediment depocenter just off the continental shelf break. "Wt." stands for "weight".

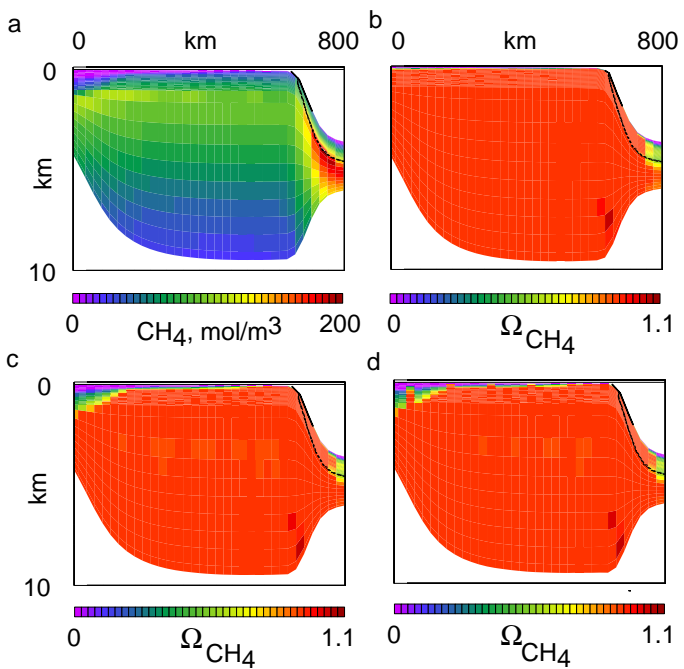

Figure 4. Initial distribution of dissolved methane. (a) Concentration in moles $\mathrm{m}^{-3}$. Panels (b-d) show $\Omega=\mathrm{CH}_{4} / \mathrm{CH}_{4}$ (sat) deviation from equilibrium: (b) of the marine (salty) initial condition, (c) of the prefreshened initial condition (note depletion in near-surface near-shore sediments in the upper left), and (d) including permeable channels every five grid points plus prefreshening.

\subsubsection{Sea level}

The simplest scenario (SL) varies the sea level while keeping the air and water temperatures time-invariant. The sea level air temperature is maintained at $0^{\circ} \mathrm{C}$. This simulation is nearly permafrost-free, with a small exception where the altitude of the sediment surface is much higher than sea level (due to the lapse rate in the atmosphere). There is no deposition of sediment above sea level in this simulation.

\subsubsection{Glacial climate}

Permafrost formation is added in simulation GL, in which the air temperature is reduced to $-16^{\circ} \mathrm{C}$ at sea level, linearly 
Table 1. Nomenclature of the model scenarios and sensitivity runs.

\begin{tabular}{|c|c|}
\hline Fr & $\begin{array}{l}\text { The sediment column has been prefreshened by previous exposure to hydrological } \\
\text { forcing. }\end{array}$ \\
\hline $\mathrm{Mr}$ & Initial salinities are close to marine. \\
\hline SL & Sea level changes with constant air and water temperatures. \\
\hline GL & $\mathrm{SL}+$ glacial cycles in air and water temperature. \\
\hline GW & $\begin{array}{l}\text { A long-term global warming scenario, a peak and long-tail temperature perturbation } \\
\text { consistent with } \mathrm{CO}_{2} \text { release and cessation of the glacial sawtooth forcing. }\end{array}$ \\
\hline $\mathrm{GW}+\mathrm{SL}$ & $\begin{array}{l}\text { Adds geologic-timescale sea level rise due to anthropogenic climate change, based } \\
\text { on correlation between temperature and sea level in the geologic past }\left(10 \mathrm{~m}^{\circ} \mathrm{C}^{-1}\right) \text {. }\end{array}$ \\
\hline $\mathrm{Ctl}$ & An extended interglacial with no $\mathrm{CO}_{2}$ release forcing. \\
\hline$+\mathrm{LD}$ & $\begin{array}{l}\text { Land deposition of carbon-rich Yedoma. Base case is } 10 \mathrm{~m} 100 \mathrm{kyr}^{-1} \text {, with sensitiv- } \\
\text { ity runs using } 30 \text { and } 100 \mathrm{~m} 100 \mathrm{kyr}^{-1} \text { accumulation of } 30 \% \text { POC material. Movies } \\
\text { in the Supplement are identified by the tags Land } 30 \text { and Land } 100 \text {. }\end{array}$ \\
\hline$+\mathrm{TG}$ & $\begin{array}{l}\text { Thermogenic methane production rate sensitivity runs, scaling the rate from the } \\
\text { spinup result by factors of } 10 \text { and } 100 \text {. Movies in the supplemental material are } \\
\text { identified by the tags TGenX10 and TGenX100. }\end{array}$ \\
\hline + Geotherm & $\begin{array}{l}\text { Sensitivity of ice and hydrate cycles on the geothermal temperature gradient. Tem- } \\
\text { peratures from the base simulation were adjusted when calculating the stability of } \\
\text { ice and hydrate to simulate the impact of geothermal heat fluxes on hydrate stability. } \\
\text { Note that other aspects of the sediment column, including the solubility of methane, } \\
\text { retained the original temperatures. Heat fluxes simulated include } 25 \mathrm{~mW} \mathrm{~m}^{-2}, 37.5 \text {, } \\
50 \text { (base), } 62.5 \text {, and } 75 \text {. Movies of the non-base runs are identified by tags HF050, } \\
\text { HF075, HF125, and HF150. }\end{array}$ \\
\hline $\begin{array}{l}\text { Ice and Bubble } \\
\text { Transport }\end{array}$ & $\begin{array}{l}\text { When the ice fraction exceeds a threshold value methane gas flow is disabled. Base } \\
\text { case is } 50 \% \text {; variants are } 10,30,70 \text {, and } 90 \% \text {, identified by the tags Ice } 10 \text {, Ice } 30 \text {, } \\
\text { Ice } 70 \text {, and Ice } 90 \text {. }\end{array}$ \\
\hline No Ice & $\begin{array}{l}\text { The ice phase is disallowed in the thermodynamic calculation. Movies in the sup- } \\
\text { plemental material include salinity. The files are tagged as NoIce }\end{array}$ \\
\hline No Salt from Ice & $\begin{array}{l}\text { Ice is allowed to form, but it does not affect the salinity as it determines methane } \\
\text { hydrate stability. Movie files are tagged as NoSalFromIce. }\end{array}$ \\
\hline $\begin{array}{l}\text { Permeable } \\
\text { Channels }\end{array}$ & $\begin{array}{l}\text { Increasing vertical permeability by a factor of } 10 \text { every fifth grid cell to generate } \\
\text { heterogeneity in the flow. Tagged as PermChan. }\end{array}$ \\
\hline $\begin{array}{l}\text { No Horizontal } \\
\text { Flow }\end{array}$ & Horizontal flow is disabled. Tagged as NoHFlow. \\
\hline
\end{tabular}

with the glacial sea level fall (Fig. 5b). In the ocean, shelf waters are always $-1.8^{\circ} \mathrm{C}$, but an interglacial subsurface temperature maximum of $1^{\circ} \mathrm{C}$ at $200 \mathrm{~m}$ decreases to $-1.8^{\circ} \mathrm{C}$ during glacial times.

\subsubsection{Deposition of carbon on land}

The deposition of organic-rich sediments when the surface is exposed to the atmosphere (Yedoma: represented as accumulation of $10 \mathrm{~m}$ in $100 \mathrm{kyr}$, with $30 \%$ POC) is added in scenarios SL + LD and GL + LD (LD for land deposition).

\subsection{Anthropogenic global warming forcing}

\subsubsection{Long-term climate impact from $\mathrm{CO}_{2}$ addition}

The global warming (GW) scenario begins from a high sea level interglacial state and raises the temperature following the climate impact of the "spike and long-tail" time distribution of a slug of new $\mathrm{CO}_{2}$ added to the atmosphere (Archer et al., 2009; Fig. 8). There is a stage of fast atmospheric drawdown as $\mathrm{CO}_{2}$ invades the ocean, but once the ocean, atmosphere, and land surface reach equilibrium (after a few hundred years), the $\mathrm{CO}_{2}$ content of the entire biosphere begins to 


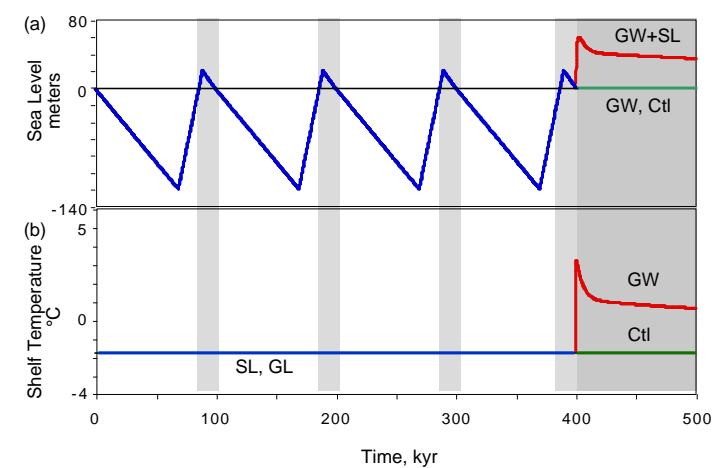

Figure 5. Time-dependent forcing for the glacial-interglacial simulations and the global warming scenarios. (a) Sea level is imposed as a sawtooth $100 \mathrm{kyr}$ cycle, with interglacial intervals shaded. The $\mathrm{GW}+\mathrm{S}$ simulation tracks potential changes in sea level on long timescales due to fossil fuel $\mathrm{CO}_{2}$ release, following a covariation from the geologic past of $15 \mathrm{~m}^{\circ} \mathrm{C}^{-1}$. The GW and control simulations hold sea level at interglacial levels. (b) Ocean temperature forcings.

relax toward an initial "natural" value, on timescales of hundreds of thousands of years, by weathering reactions with carbonate and siliceous solid rocks. The net result is a $\mathrm{CO}_{2}$ drawdown that can be expressed as the sum of several exponential functions in time, with timescales ranging from $10^{2}$ to $10^{6}$ years.

Changes in water column temperature are assumed to be equal to those of the atmosphere, following paleoceanographic reconstructions (Martin et al., 2002) and long-term coupled ocean-atmosphere circulation model experiments (Stouffer and Manabe, 2003). The GW scenario imposes this temperature change on the water column, relaxing toward equilibrium with the atmospheric $\mathrm{CO}_{2}$ trajectory with a time constant of 100 years.

\subsubsection{Long-term behavior of sea level}

The effect of sea level rise is added to create a second global warming scenario, GW + SL. On timescales of thousands of years, the sea level response to changing global temperature is much stronger than the sea level response over the coming century, as prominently forecast by the IPCC. The reconstruction of sea level and global temperature covariation in the geologic past (glacial times to Eocene hothouse) reveals a covariation of $10-20 \mathrm{~m}^{\circ} \mathrm{C}^{-1}$ (Archer and Brovkin, 2008). The global warming with sea level scenario assumes an equilibrium sea level response of $15 \mathrm{~m}^{\circ} \mathrm{C}^{-1}$ which it relaxes toward with a time constant of 1000 years.

\subsection{Sensitivity studies}

A strategy for dealing with the many uncertainties in the model formulation and parameterization is to do sensitivity studies to determine which of the unknowns are most signif- icant. The model sensitivity studies are summarized in Table 1 . Sensitivity studies on the rates of methane production have already been mentioned, as have the prefreshened versus marine initial conditions, representing uncertainty in the salt content of the sediment column. Other model sensitivity runs include the geothermal temperature gradient and a parameterization of the permafrost inhibition of bubble migration. Several altered-physics runs were done - one adding vertical permeable channels, one disabling horizontal flow, and several to evaluate the impact of ice formation on methane hydrate stability.

\section{Results}

\subsection{Glacial cycles}

\subsubsection{Salinity}

In the "prefreshened" initial condition (Fr), millions of years have elapsed since the previous exposure of the sediment to hydrological forcing, but a core of freshwater remains. Salinities near the sediment surface have grown saltier due to diffusive contact with seawater (Fig. 6, left). A fully marine initial condition (Mr; Fig. 6, right) was initialized from the unfreshened case, in which sea level was held at a fixed value throughout the $65 \mathrm{Myr}$ spinup of the sediment column. The salinities are nearly uniform in this case.

When the sediment surface is re-exposed to the atmosphere during an interval of low sea level, in the absence of ice formation (simulation SL), the surface layer tends to freshen relatively quickly due to the hydrological forcing, although a subsurface salinity maximum persists (Fig. 6c and d). If the air temperatures are cold enough to form ice (simulation GL), surface salinities in the model increase to up to nearly $190 \mathrm{psu}$ in both the prefreshened and pure marine cases (Fig. 6e and f). By the next interglacial period (Fig. $6 \mathrm{~g}$ and $h$ ), ice near the sediment surface has melted enough for near-surface pore waters to reach relatively low salinities.

\subsubsection{Pressure and flow}

The effect of the glacial-interglacial sea level and climate forcing on the pressures and flow velocities is shown in Fig. 7. On a spatial scale of the entire model domain (Fig. 7, left), the highest driving pressures are found at the base of the sediment column, underneath the region of maximum sediment accumulation (the depocenter just off the shelf break). Changes in sea level drive large fluctuations in the pressure head (contours) extending to bedrock. In the near-surface continental shelf (Fig. 7, right), the driving pressure variations are dominated by the pressure head, driven by sea level changes. The formation of permafrost (GL, Fig. 7e and f) seals the upper sediment column to fluid flow.

When sea level rises again, in the model configuration including permafrost, there is a strong pulse of downward flow 


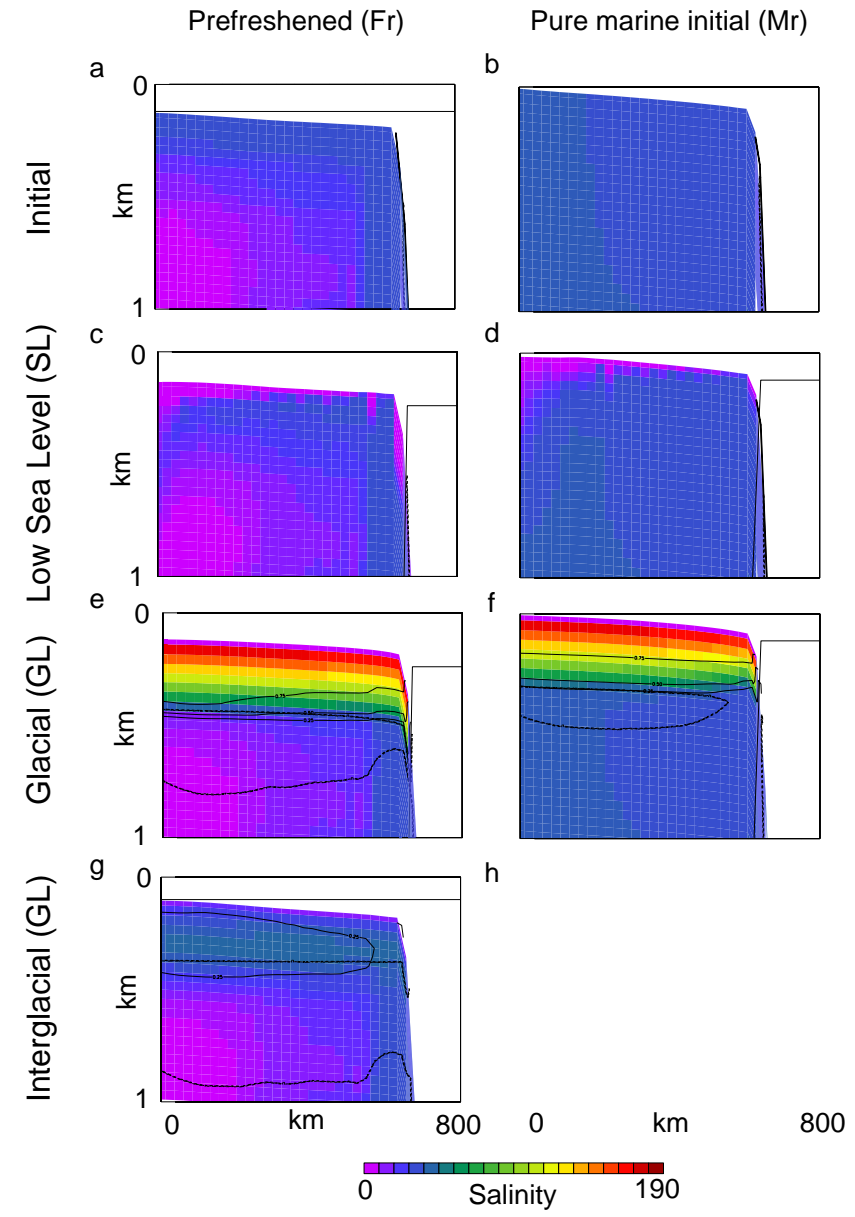

Figure 6. Colors indicate salinity in the unfrozen pore fluid of the sediment column. Thin solid black contours show the frozen fraction of the pore space. Heavy black stippled contour shows the stability boundary of methane hydrate as a function of temperature, pressure, and unfrozen pore fluid salinity. Left side: previously prefreshened initial condition. Right side: pure marine initial condition. Panels (c-d) show lowered sea level (from 70 kyr in Fig. 8) but warm air temperatures prevent permafrost formation. Panels (ef) show glacial conditions of lowered sea level $(70 \mathrm{kyr})$ and atmospheric temperature of $-17^{\circ} \mathrm{C}$ driving permafrost formation. The prefreshened and the marine initial conditions differ in the frozen fraction of sediment, but the salinity of the unfrozen fluid, a correlate of the activity of water, depends only on the temperature. Panels (g-h) show rising sea level (at $90 \mathrm{kyr}$ in Fig. 8) during an interglacial interval. Movies of the glacial cycles (GL) with the prefreshened initial condition can be seen at http://geosci.uchicago. edu/ archer/spongebob_arctic/fig6a.movie.gif, and movies of the marine initial condition can be seen at http://geosci.uchicago.edu/ archer/spongebob_arctic/fig6b.movie.gif.

following partial melting of the permafrost (Fig. 7h). It is possible that this flow, which lasts a few thousand years, is an artifact of the elastic model configuration, in which the release of a load (by submergence of the upper sediment column into the ocean) provokes the expansion of pore spaces

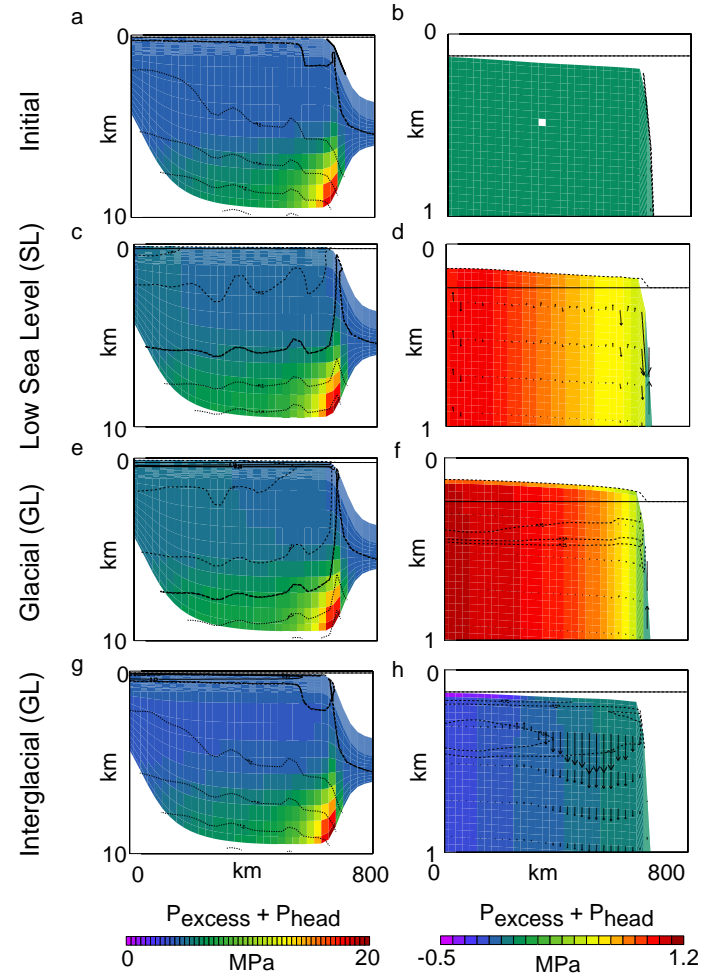

Figure 7. Pore fluid pressure forcing and flow through the glacial cycles. Left: colors indicate $P_{\text {excess }}+P_{\text {head }}$, solid contours are ice fraction, and dashed contours are $P_{\text {head }}$. Right: colors indicate $P_{\text {excess }}+P_{\text {head }}$; note different color scale from left. Initial refers to the prefreshened initial condition. "Low Sea Level" refers to simulation SL. "Glacial" and "Interglacial" refer to simulation GL. Dashed contours indicate ice fraction; vectors indicate fluid velocity. Movies can be seen at http://geosci.uchicago.edu/ archer/ spongebob_arctic/fig7a.movie.gif and http://geosci.uchicago.edu/ $\sim$ archer/spongebob_arctic/fig7b.movie.gif.

in the sediment. The anomalous flow, integrated over its duration, could displace the pore fluid by about $40 \mathrm{~m}$, which is less than one grid cell. The model configuration without the sealing effect of permafrost (SL) does not show this pulse of invasive flow on sea level rise.

\subsubsection{Methane cycle}

There are multiple ways in which the glacial cycles of sea level and air and water temperature might impact the flux of methane to the atmosphere. Submergence in the ocean is one modulating factor because the emerging bubbles dissolve in the ocean rather than reaching the atmosphere. Another factor is the deposition of high-POC surface soils during low sea level stands and its exposure to degradation later when the permafrost soils melt. A third factor is permafrost, impeding gas and fluid flow and excluding dissolved methane and salt from ice formation. The impacts of these processes 


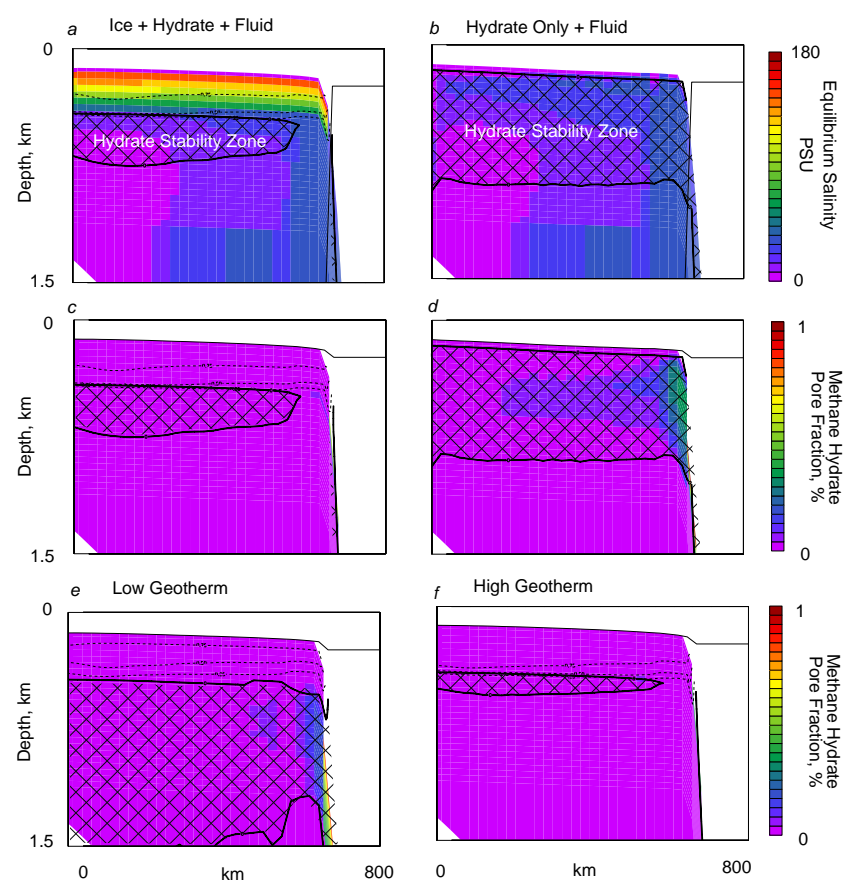

Figure 8. Sensitivities of the hydrate stability zone. Impact of the competition between ice and hydrate phases (a-d), and the geothermal temperature gradient (e-f). When ice is included as a potential solid phase, the pore waters are salty in the permafrost zone (a), restricting hydrate stability to at least $300 \mathrm{~m}$ below sea level throughout the simulation (c). When ice is forbidden to form, hydrate can be stable nearly to the sediment surface during the height of the glaciation (b) and (d). The base of the stability zone is sensitive to the geothermal temperature gradient, while the shallowest reach of the stability zone does not respond to changing heat fluxes because the temperatures are "anchored" at the ocean value at the top of the sediment column.

are assessed by comparing the results from model configurations with and without each process in question.

\section{Ice vs. hydrate}

The impact of phase competition between ice and hydrate is shown in Fig. 8. In the base scenario (Fig. 8a and c) hydrate stability is excluded from the permafrost zone as described in Text S3. Preventing ice from forming in an altered-physics simulation (+ No Ice) decreases the fluid-phase salinity relative to the base simulation and allows the methane hydrate stability zone to nearly reach the sea floor (Fig. 8b and d) during strongest glacial conditions. Another altered-physics simulation was done, in which ice is allowed to form but not to affect the salinity as it drives methane hydrate stability (which was hardwired to marine salinity). Methane hydrate is still unstable in the permafrost zone through most of the simulation (see movie files in the Supplement), indicating that thermal interaction must also have a strong impact on methane hydrate stability in the permafrost zone.

\section{Dissolved methane}

The evolution of the dissolved methane disequilibrium condition $\left(\mathrm{CH}_{4} / \mathrm{CH}_{4 \mathrm{sat}}\right)$ is shown in Fig. 9. At the initiation of the glacial cycles, methane is undersaturated in near-surface sediments on the continental shelf by diffusive contact with the methane-free ocean upper boundary condition. In the prefreshened sediment column scenario $(\mathrm{Fr})$, methane concentrations in the depth range of 100-1000 $\mathrm{m}$ are lower than in the marine case (Mr, Fig. 9b) due to the ventilation by the hydrological pump (Fig. 9a). Further freshening of the pore waters in the ice-free case (SL $+\mathrm{LD}$ ) tends to deplete methane in the upper sediment column (Fig. 9c-e), while methane exclusion from the permafrost ice leads to supersaturation in simulation GL + LD (Fig. 9f-h). The hydrate stability zone is somewhat expanded in the prefreshened sediment column relative to the marine case (Fig. $9 \mathrm{~g}$ vs. h, heavy black contour).

\section{Methane sources}

Figure 10 shows snapshot sections of various aspects of the shelf carbon cycle, beginning from a prefreshened initial condition. Sections of POC concentration in Fig. 10, left, show the accumulation of POC-rich Yedoma deposits on land (Fig. 10g and $\mathrm{j}$ ). The rate of methane production in the model (Fig. 10, right) depends on temperature and organic-carbon age, but it is also attenuated by permafrost formation in the model, scaling to 0 in the completely frozen case. Methanogenesis rates are near 0 in the permafrost zone during glacial times (Fig. 10h) but partially recover during interglacial times (Fig. 10k) even though permafrost is still present.

\section{Hydrate}

A zone of methane hydrate stability exists below the permafrost zone when permafrost is present, and some methane hydrate accumulates in that zone. The highest pore-fraction values are found near the continental slope, where the shelf stability field outcrops within the slope depocenter. Dissolved methane concentrations exceed saturation within the stability zone in the model (Fig. 9), but the accumulation of methane hydrate (Fig. 10, right) is limited by the rate of methane production.

Time series plots of the inventory of methane as hydrate on the shelf are shown in Fig. 11. The integration cuts off at $x=560 \mathrm{~km}$ to exclude the sediment depocenter on the continental slope. Hydrate inventories reach maximum values during deglaciations. There is more hydrate when the pore water is fresher, and there would be more if ice were prevented from forming (Fig. 11a). The hydrate inventory is much more sensitive to thermogenic methane production, deep in the sediment column, than Yedoma deposition (Fig. 11b). The impact of the geothermal heat flux is to change the depth of 


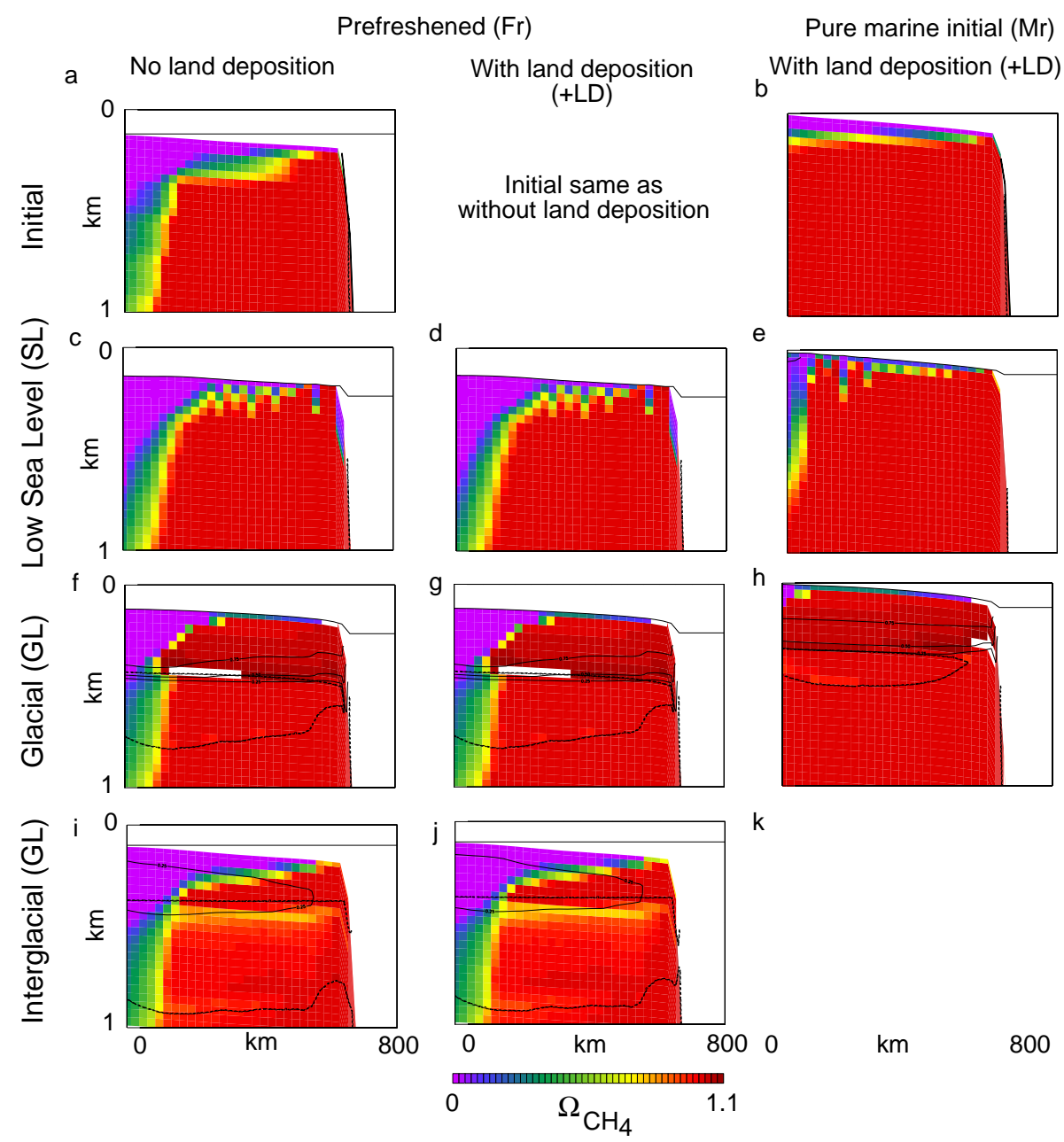

Figure 9. Dissolved methane concentration relative to equilibrium $\left(\Omega=\mathrm{CH}_{4} / \mathrm{CH}_{4}\right.$ (sat) $)$. Solid contours indicate ice fraction; dashed contours show the methane hydrate stability boundary. Movies for the left, center, and right columns, respectively, can be seen at http://geosci.uchicago.edu/ archer/spongebob_arctic/fig9a.movie.gif, http://geosci.uchicago.edu/ archer/spongebob_arctic/fig9b.movie.gif, and http://geosci.uchicago.edu/ archer/spongebob_arctic/fig9c.movie.gif.

the bottom of the hydrate stability zone (Fig. 18e and f), but the impact is small on the hydrate inventory, unless the temperature gradient is so low that hydrate persists through the entire glacial cycle (Fig. 11c). The hydrate forms from the dissolved methane pool, which exceeds $1000 \mathrm{Gton} \mathrm{C}$ in shelf pore waters of the model.

\section{Permafrost, ocean, and atmospheric methane flux}

The impact of the glacial cycles on the methane pathway to the atmosphere in the model is shown in Fig. 12. When sea level is high, the efficiency with which bubbles that escape the sediment reach the atmosphere ranges from about $75 \%$ near the coast to about $10 \%$ at the shelf break (Fig. 12a). Most of the methane flux from the sediment is located just off the shelf break (Fig. 12e), where the escape efficiency is low, so not much methane makes it to the atmosphere during the interglacial. During glacial times, the sediment column is exposed to the atmosphere, and the escape efficiency in the model is $100 \%$ (Fig. 12b). Permafrost inhibits the terrestrial methane flux (Fig. 12i) relative to the case without permafrost (Fig. 12f). During some deglaciations, the release of pent-up gas by permafrost degradation leads to a spike of excess methane flux to the atmosphere (Fig. 12j-k relative to $\mathrm{g}-\mathrm{h}$ ).

\section{Budget}

Time series plots of the major fluxes of the methane cycle on the continental margin are shown in Fig. 13. The methanogenesis rates in the model output are in units of moles per meter of coastline, since it is a two-dimensional model. We scale this up to the Siberian continent $\left(\times 10^{11} \mathrm{~m}^{2}\right)$, roughly comparable to the real shelf area of $460000 \mathrm{~km}^{2}$ (Stein and Fahl, 2000). The biological rate of methane production on the continental shelf evolves through time in Fig. 13b. Yedoma 

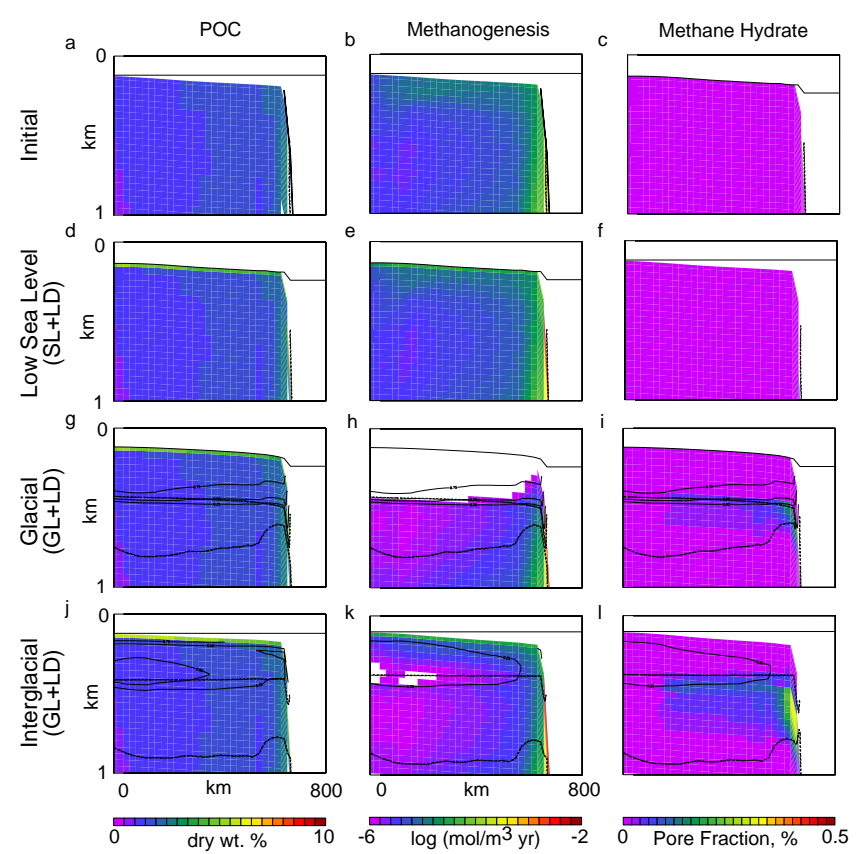

Figure 10. Carbon cycle through glacial cycles from a prefreshened initial condition. Solid contours: ice fraction. Dashed contours: methane hydrate stability zone. Left: particulate organic carbon (POC) concentration ("wt" stands for "weight"). Movie at http: //geosci.uchicago.edu/ archer/spongebob_arctic/fig10a.movie.gif. Center: biological methane production rate. Movie at http: //geosci.uchicago.edu/ archer/spongebob_arctic/fig10b.movie.gif. Right: methane hydrate concentration. Movie at http: //geosci.uchicago.edu/ archer/spongebob_arctic/fig10c.movie.gif. Movies of methane hydrate stability and concentration are given for the sensitivity studies in Supplement and at http://geosci.uchicago.edu/ archer/spongebob/.

deposition (case SL + LD) tends to slowly increase the total shelf respiration rate in the model, relative to a case with no land deposition (case SL). The formation of permafrost, during glacial periods of case GL + LD, attenuates methanogenesis by inhibiting biological activity in the frozen soil.

The solid regions in Fig. 13c-h are cumulative methane sinks for six different model scenarios, plotted underneath red lines showing biogenic methane production. In time average, where sinks balance sources, the colored areas should fill up the region below the red line.

The trapping of methane by impermeable permafrost leads to a spike of methane fluxes at the ends of deglaciations in simulations with permafrost (Fig. 13c and e). The spikes happen as sea level approaches its highest extent, stifling the offshore groundwater flow by decreasing the pressure head, but they occur early in the interglacial period while permafrost is the most intact. The spikes are stronger for the first glacial cycles than the last, apparently due to long-term adjustment of the methane cycle on the shelf (a convergence of the pro-

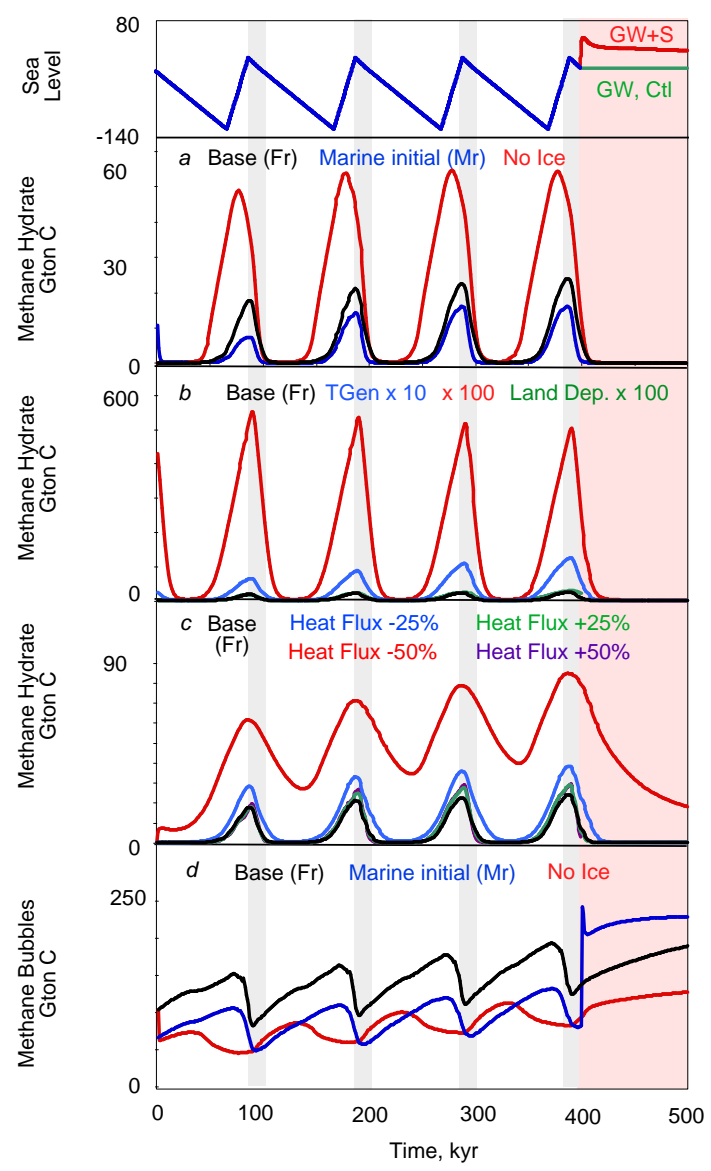

Figure 11. Glacial cycle of methane hydrate inventory on the continental shelf. (a) Effects of salt and ice. (b) Sensitivity to methanogenesis rates. (c) Sensitivity to the column temperature gradient. (d) Glacial cycles of shelf bubble inventories, and effects of salt and ice.

duction rate (red lines in Fig. 13c-f) and the various methane sinks (colored areas)).

Permafrost formation blocks methane emission during times of low sea level. This can be seen in the collapse of the blue regions in Fig. 13c vs. $d$ and e vs. f during times of low sea level. Blocking horizontal flow disrupts offshore flow, the only significant methane sink on the shelf during glacial periods (Fig. 13h), resulting in somewhat higher deglacial spikes of methane emission than predicted by the models including transport. There is no direct link between ice fraction and methane oxidation in the model, which is driven only by coexisting concentrations of sulfate and methane, but the rate of methane oxidation also drops to negligible levels during glacial times in the simulations with permafrost (grey in Fig. 13c and e). The absolute rates of methane loss differ between the prefreshened vs. marine initial conditions, but this is in part due to differences in the width of the continental shelf between the two simulations. The patterns of the methane cycle are very similar, however, between the two 


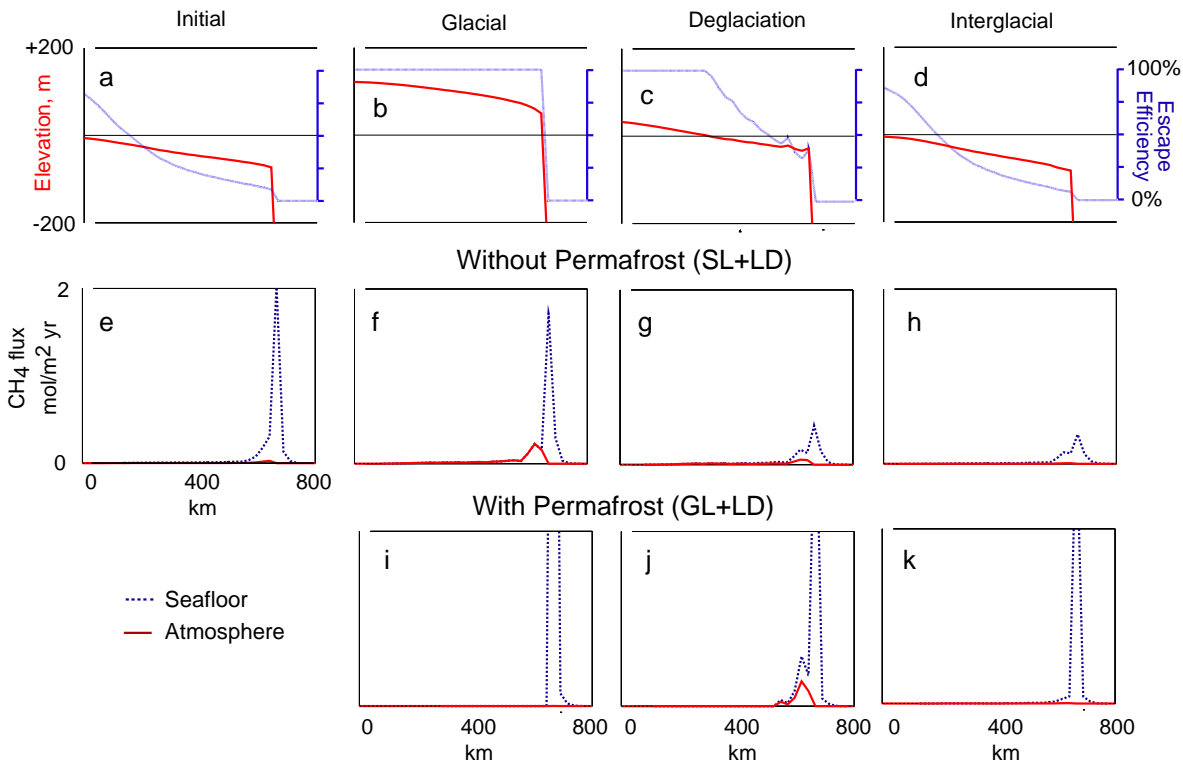

Figure 12. Spatial distribution and sea level impact of methane fluxes to the atmosphere. Panels (a-d): solid line shows the elevation of the sediment surface relative to the sea level at the time. Blue lines (scale to right) show the efficiency of bubble transport through the water column, assuming a flux attenuation length scale of $30 \mathrm{~m}$. Red lines show the batymetry. Panels (e-k): dashed blue line: methane bubble flux across the sediment surface. Solid red line: methane bubble flux to the atmosphere (dashed line multiplied by transport efficiency). Most of the methane flux in the model occurs near the shelf break, and submergence in the ocean has a strong impact on the flux to the atmosphere. A related movie can be seen at http://geosci.uchicago.edu/ archer/spongebob_arctic/fig12.movie.gif.

cases and are also not much affected by the imposition of permeable vertical channels (Fig. 13g).

\section{Atmospheric flux}

Fluxes of methane to the atmosphere are shown in Fig. 14. In the absence of permafrost (Fig. 14a and b), or assuming that bubble migration is blocked only if the ice fraction exceeds $90 \%$, a condition rarely attained in the model (Fig. 14e), the highest methane fluxes to the atmosphere are found during glacial (cold) times rather than warm interglacials. This is due to the dissolution of methane gas into the ocean when the sediment column is submerged. When permafrost blocks methane gas fluxes in the sediment column, the highest atmospheric fluxes are generally found during the time of early sea level fall, when unfrozen sediment is exposed to the atmosphere before it has a chance to freeze. The timing of the variations in atmospheric flux through the glacial cycles is very sensitive to the critical ice fraction for blocking gas transport (Fig. 14e).

The impacts of the pore water salt inventory are most apparent during the time of sea level fall, with permafrost formation (red lines). The saltier sediment column takes about $20 \mathrm{kyr}$ to choke off the methane flux to the atmosphere (Fig. 14a), while the prefreshened sediment column stops the methane flux more abruptly, in just a few thousand years (Fig. 14b). Atmospheric emissions also scale with methane production rates, generally maintaining the temporal patterns of emission as set by permafrost and submergence in the ocean.

\subsection{Anthropogenic global warming}

The atmospheric methane fluxes, shown in Fig. 15, increase in the global warming (GW) model run, as they also do in the control $(\mathrm{Ctl})$ simulation, which is essentially an extended but unwarmed interglacial period. The permafrost melts on a timescale of about 10000 years for the GW simulation, and about 50000 for the Ctl. The rates of methane production and flux to the atmosphere both increase with the loss of the permafrost, if there is no change in sea level. However, the new methane flux comes not as a sudden burst but rather as a slow transition toward a new, higher, chronic release rate.

When sea level is also changed $(\mathrm{GW}+\mathrm{SL})$, bubbles dissolve in the water column, which more than counteracts the increase in methane flux due to the extended interglacial $(\mathrm{Ctl})$ or warming $(\mathrm{GW})$ scenarios.

\subsection{Sensitivity studies}

\subsubsection{Sediment salt content}

Ice freezes until the salinity of the residual brine brings about a freezing point depression equal to the in situ temperature. A saltier initial sediment column will reach this condition with a lower ice fraction, its melting is accelerated, and its hydrate inventory is lower (Fig. 14). The equilibrium salinity 


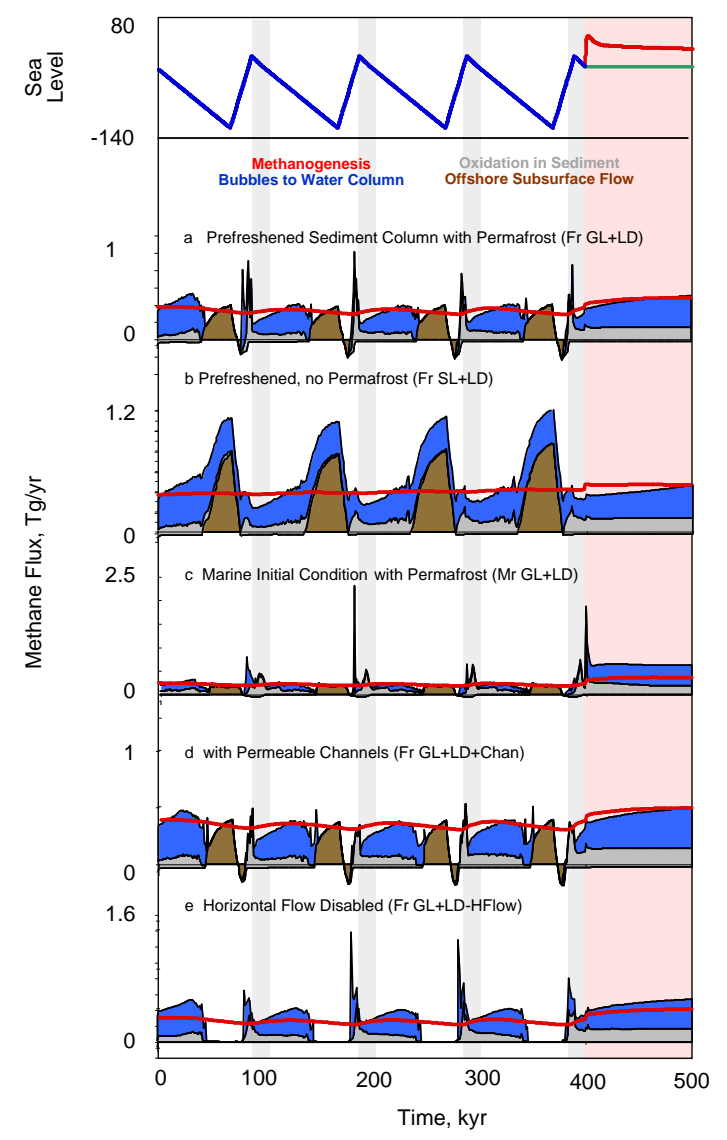

Figure 13. Glacial-interglacial cycle of methane fluxes on the continental margin of the model. Sea level is shown at top, with grey regions indicating interglacial intervals and pink the Anthropocene. (a-e) Cumulative methane fluxes. Red lines show production rate. Brown regions show lateral transport of dissolved methane. Grey shows oxidation by $\mathrm{SO}_{4}^{2-}$ in the sediment column. Blue shows bubble flux to the water column. During interglacial times (e.g., far left) there is a small onshore transport of methane, which is represented by a negative starting point for the oxidation (grey) region. In equilibrium, the colored areas should fill in the area under the red curve.

in the permafrost zone is not affected by the salt inventory of the column, only the relative volumes of the solid and fluid phases.

\subsubsection{Methane production rates}

The atmospheric flux increases along with either shallow, biological methane production, driven by deposition of Yedoma, or thermal methane production in the deep sediment column (Fig. 15). Biogenic methane production is too shallow in the sediment column to impact the inventory of methane hydrate (Fig. 11). The timings through the glacial cycles of atmospheric methane emissions from these scenarios parallel each other because they are controlled in common by the transport-blocking effects of permafrost and sediment submergence in the ocean.

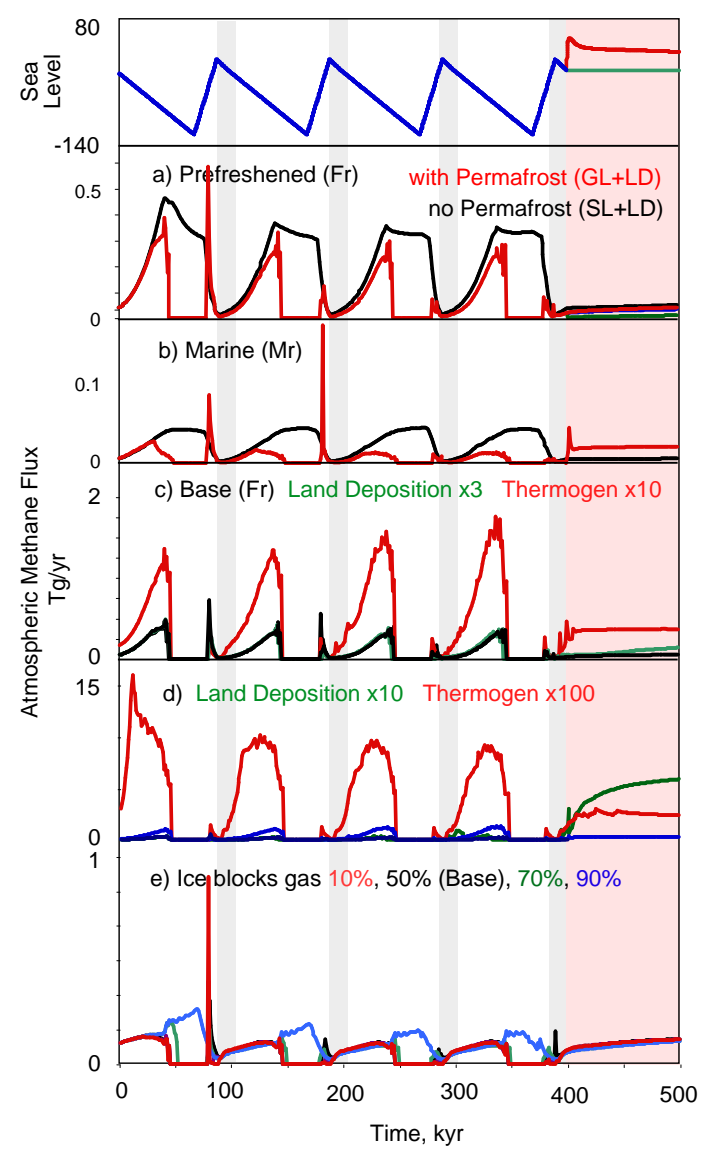

Figure 14. Methane fluxes to the atmosphere. Sea level is shown at the top, with interglacial intervals displayed as vertical grey bars and the Anthropocene in pink. Panel (a) shows methane fluxes from a prefreshened initial condition, with and without permafrost formation. Panel (b) shows methane fluxes from a pure marine initial condition. Panels (c) and (d) show sensitivity to terrestrial organiccarbon deposition as stands during low sea level and to thermogenic methane flux. Panel (e) shows sensitivity to the impact of the ice fraction on bubble mobility.

\subsubsection{Geothermal temperature gradient}

When the heat flux is higher, the temperature gradient is steeper, pivoting about the sediment surface temperature, which is set by the ocean. The base of the methane hydrate stability boundary becomes shallower, while the top remains at about the same depth, resulting in a thinning of the stability zone (Fig. 8). The hydrate inventory through the glacial cycles, however, is not much affected, unless the heat flux becomes small enough for hydrate to persist through the glaciations (Fig. 11).

\subsubsection{Thermodynamic competition between ice and hydrate}

When ice is included as a competing phase, it excludes methane hydrate from the low-pressure, very cold permafrost 


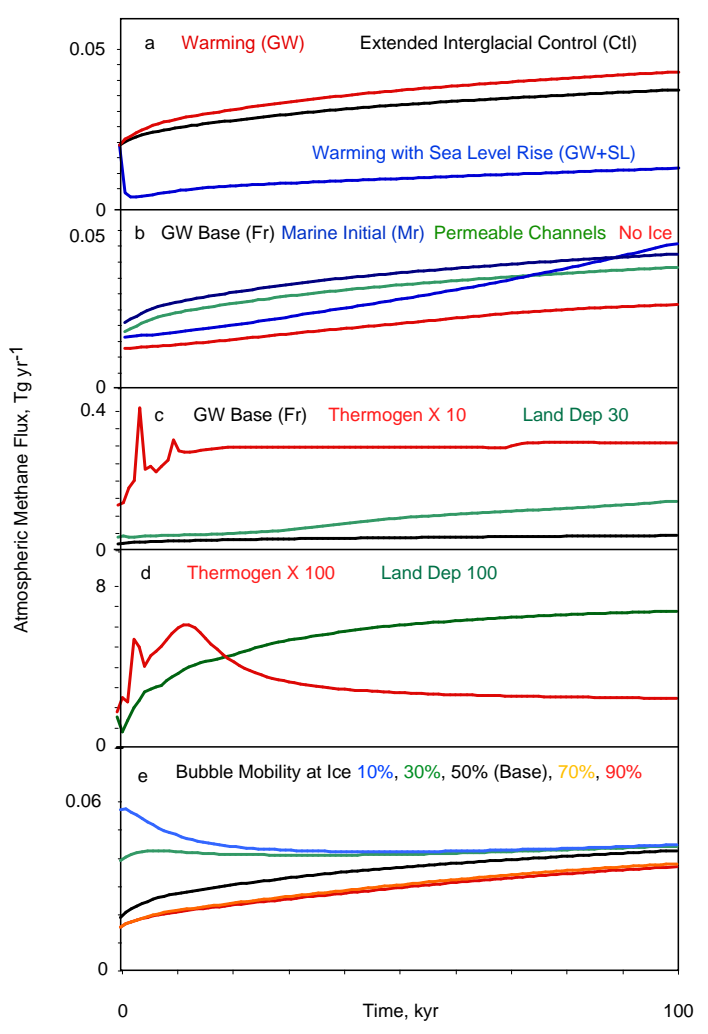

Figure 15. Impact of anthropogenic warming on the methane cycle in the model. Panel (a) shows base cases: a warming scenario (GW), without and with a geological timescale sea level rise scenario (+SLR), and extended interglacial control ( $\mathrm{Ctl})$. Warming plus increasing sea level decreases the methane flux overall, due to bubble dissolution in a deeper water column. Panel (b) shows altered model physics impacts. Panels (c) and (d) show altered methanogenesis rates. Panel (e) shows the sensitivity to the ice fraction at which bubble mobility is assumed to be stopped.

zone. The hydrate stability zone thins (from above and below in the model: Fig. 8), and the hydrate inventory decreases (Fig. 11). When ice formation is disallowed, the hydrate stability zone approaches the sediment surface during coldest glacial times, but by the time of an interglacially based global warming climate perturbation, the stability zone boundary has retreated to several hundred meters below the sea floor, precluding a sudden hydrate dissolution response to a suddenly warming ocean.

When the ice fraction of the model exceeds a critical threshold, gas migration is blocked. Changing the value of this threshold has a strong impact on the rates of methane emission during glacial versus interglacial times. This process is therefore a high priority for future model refinement.

\subsubsection{Vertical flow heterogeneity}

The chemistry of continental-margin sediments in this model (Archer et al., 2012) showed a strong sensitivity to flow het- erogeneity, achieved by increasing the vertical permeability of every fifth grid cell. In the configuration presented here, the impact of the channels is much smaller. The dynamics of this simulation are thermally driven, rather than by sediment deposition driving fluid flow in the continental-margin case. Atmospheric methane fluxes are spikier when the channels are included, but the mean rate is not much changed.

\subsubsection{Groundwater flow}

Groundwater flow carries enough methane to be a significant sink during times of low sea level. However, disabling that flow has only subtle impacts on the other aspects of the methane cycle on the shelf. Spikes of methane emission during late deglaciation become somewhat more intense.

\subsection{Comparison with observations}

The model bubble flux to the atmosphere in the base case in analog present-day conditions is $0.02 \mathrm{Tg} \mathrm{CH}_{4}$ per year, which is an order of magnitude lower than an estimate of the total methane emission rate from the sea surface (bubbles + gas exchange; Kort et al., 2012) of $0.3 \mathrm{Tg} \mathrm{CH}_{4} \mathrm{yr}^{-1}$. The model does not include gas exchange evasion of methane from the sea surface, which could be significant. Concentrations of methane in the water column of $50 \mathrm{nM}$ are common (Shakhova et al., 2010a); if they were unimpeded by sea ice, they could lead to a flux of $0.4 \mathrm{Tg} \mathrm{CH}_{4} \mathrm{yr}^{-1}$ from the region (assuming a typical gas exchange piston velocity of $3 \mathrm{~m} \mathrm{day}^{-1}$ ). Gas exchange is impeded by sea ice, but it can be enhanced by storms (Shakhova et al., 2013). Once released to the water column, the fate of a methane molecule will depend on its lifetime with respect to oxidation, which could be up to a year in the open-water column (Valentine et al., 2001), versus its lifetime with respect to gas exchange, which for ice-unimpeded conditions would be just a few months for a $50 \mathrm{~m}$ deep water column. Thus, the methane in bubbles dissolving in the water column has some chance of making it to the atmosphere anyway, depending on stratification in the water column and the extent of ice, and the gas exchange flux has the potential to be significant in the regional total flux.

Methane fluxes into the water column range up to $0.4 \mathrm{Tg} \mathrm{CH}_{4} \mathrm{yr}^{-1}$ during times of relatively high sea level. This is much lower than the Shakhova et al. (2013) estimate of $17 \mathrm{Tg} \mathrm{CH}_{4} \mathrm{yr}^{-1}$ from hot-spot ebullition fluxes to the water column. The model fluxes are comparable to these observations when the thermal methane flux is increased by a factor of 100 (see Sect. 3.3.2), but the model lacks the physical or mechanistic detail required to focus the emissions into hot spots of concentrated methane flux as observed (Sect. 4.1). 


\section{Discussion}

\subsection{Limitations of the model results and critical issues for future development}

This is the first simulation of the full methane cycle on the Siberian continental margin, or any other location with embedded permafrost soils, including hydrate formation and transient fluxes. It is internally consistent, linking processes from the ocean, the sea floor, and the deep Earth, within constraints of sediment accommodation and conservation of carbon, through geologic time. As such it has some lessons to teach about the real Siberian continental margin. However, many of the model variables are not well known, such as the methanogenesis rates or soil permeabilities, meaning that in some aspects the model results are not a strong constraint on reality. These uncertainties illuminate critical issues for future model refinement.

\subsubsection{Methane production rates}

The rates of biological and thermal methane production on the Siberian continental shelf are not well constrained by laboratory measurements or field inferences. These rates are treated as tunable model parameters, and the sensitivity studies show that they are important ones to ultimately get right.

\subsubsection{Gas transport in the sediment column}

Simulating the hot-spot behavior of bubble emission from the sea floor will also require more detailed treatment of the mechanisms by which gas moves around in the sediment column. The model lacks faults and permeable layers that act as transport highways and hydrate depocenters and may concentrate the flow into a hot-spot ebullition region. The model also lacks the ability to episodically "blow out", producing the sedimentary wipe-out zones observed seismically in the subsurface (Riedel et al., 2002) and the pockmarks at the sediment surface (Hill et al., 2004). The steady-state hydrate inventory in the model is extremely sensitive to the bubble vertical transport spatial scale (Archer et al., 2012), which determines how far a bubble can get through unsaturated conditions before it redissolves. This result demonstrates the importance of gas transport to predicting the methane hydrate or bubble inventories.

\subsubsection{Atmospheric flux efficiency}

On land, the model lacks seasonal melting of surface permafrost and the thaw bulbs underneath lakes and rivers. In the ocean, the fraction of the bubbles which dissolves in the water column depends on the bubble sizes, which depend on the gas emission rate, ultimately driven by details of gas transport in the sediment.

\subsubsection{Uncertainty in model output}

These uncertainties affect the flux of methane to the atmosphere and model predictions of the standing stocks of methane as gas and hydrate in the sediment column.

\subsection{Robust features of the simulation}

\subsubsection{Arctic Ocean methane fluxes are small in the global budget}

The model is consistent with observations (Kort et al., 2012), that the total atmospheric methane flux from the Siberian margin is a small fraction of the global flux of methane to the atmosphere and thus represents only a minor climate forcing. The model would have to be pushed very hard (as would the measurements) to fundamentally change this conclusion.

\subsubsection{The hydrological salinity ratchet}

Groundwater flow, driven by the pressure head, provides an advective means of pumping freshwater into the subsurface sediment column that has no counterpart for salty ocean water. The model lacks the mechanism of salt fingering, which can enhance the diffusion of salt from above into a freshwater aquifer (Kooi et al., 2000). However, higher-resolution models of smaller domains that accounted for salt fingering also show a time asymmetry, with faster freshwater invasion on sea level drop than salt invasion on sea level rise ( $\mathrm{Lu}$ and Werner, 2013; Watson et al., 2010). As the size of the domain increases with increasing sea level change, advective processes such as hydrological flow should become even more dominant over diffusive processes such as salt fingering. The recent discovery of vast freshwater aquifers on global continental shelves (Post et al., 2013), persisting since the time of lowered sea level 20000 years ago, and the lowerthan-marine salinities of the pore waters measured in submerged surface Arctic sediments (summarized by Nicolsky et al., 2012) are also consistent with the existence of a freshwater hydrological pump which has a significant impact on sediment column salinities.

\subsubsection{Salinity (water activity) and hydrate stability in the permafrost zone}

In the simulations the pore water salinities in the permafrost zone did not depend on the total salt content of the sediment column but only on the temperature (and secondarily on the pressure). A saltier sediment column will end up with a larger volume of brine in equilibrium than a fresher sediment column would have, but the salinities of the brines would be the same.

In the permafrost zone (low temperature and pressure), ice can tolerate higher salinity (lower water activity) than methane hydrate can. As long as there is no kinetic impediment to ice formation, bubbles of methane rising into this 
zone should encounter brine salinities too high to permit the formation of methane hydrate (Sect. A3).

\subsubsection{Sea level dominates the glacial cycle of methane flux}

The methane flux to the atmosphere through the glacialinterglacial cycles is highest during cold times because sea level is low, and it contrasts with the positive feedback response of releasing methane during warm (high sea level) intervals. Atmospheric methane concentrations were lower during glacial times than interglacials, but since the Arctic Ocean is a small fraction of the total methane budget (Sect. 4.2.1), the atmospheric concentration does not necessarily reflect Arctic fluxes.

\subsubsection{Methane emission response to anthropogenic climate change}

There is a warming positive feedback in the simulated future from climate warming, with fluxes rising gradually on a timescale of thousands of years. Shakhova et al. (2010b) proposed that $50 \mathrm{Gton} \mathrm{C}$ as methane could erupt from the Arctic on a timescale of a few years. However, the thermodynamic exclusion of methane hydrate from the permafrost zone (Sect. 4.2.2) ensures that methane hydrate will be isolated from changes in ocean temperature by $\sim 400 \mathrm{~m}$ of mud and ice. A warming perturbation at the sea floor today will not reach this depth for hundreds or thousands of years. A complex model is not really required to conclude that methane hydrate will probably not produce a methane eruption of this scale so quickly.

Could an abrupt methane release arise from the release of trapped bubbles from melting ice? The model actually does produce a glacial cycle in bubble inventory, with changes exceeding 50 Gton over a cycle, apparently driven by methane exclusion from ice formation (Fig. 11). However, the model does not deliver an abrupt release in response to anthropogenic warming for any of its sensitivity studies (Fig. 14). We would get a faster initial response to global warming if the transition from glacial to global warming sediment surface temperatures had not mostly happened thousands of years ago.
The model provides a poor constraint on the standing stock of bubbles or methane hydrate in the sediment column and neglects many of the mechanisms that could come into play in transporting methane quickly to the atmosphere, such as faults, channels, and blowouts of the sediment column. A continuum model such as this one predicts a smooth methane release response to a warming, growing on some $e$-folding timescale. A world dominated by features that each represent a small fraction of the total methane reservoir will release methane more episodically, but the statistical distribution of the response in time should still show the $e$-folding timescale of the underlying driving mechanism, the diffusion of heat into the sediment column.

The way to deliver 50 Gton of methane to the atmosphere on a short timescale is for it all to be released from a single geologic feature pent-up by ice. However, 50 Gton of $\mathrm{C}$ represents a large fraction of all the traditional natural gas deposits on Earth (about 100 Gton C). The place to look for such a large unstable gas reservoir is in the field, not in this model, but until such a thing is found it remains conjecture.

On timescales of thousands of years and longer, carbon from deep methane hydrates and frozen organics on the Siberian continental shelf could reach the atmosphereocean carbon cycle, potentially significantly amplifying the "long-tail" climate impact of anthropogenic carbon release. Methane that is oxidized in the ocean would eventually equilibrate with the atmosphere, so it is much easier for escaping methane to impact the long tail as $\mathrm{CO}_{2}$ than it is to affect the near future as methane.

The potential for future sea level change is much higher on millennial timescales than the forecast for the year 2100 because it takes longer than a century for ice sheets to respond to changes in climate. The model finds that for the future, if sea level changes by tens of meters, as indicated by paleoclimate reconstructions (Archer and Brovkin, 2008), the impact of sea level rise could overwhelm the impact of warming. The dominance of sea level over temperature in the model of this area is due to the dissolution of methane in the water column rather than a pressure effect on hydrate stability, which is generally a weaker driver than ocean temperature in deeper-water settings (Mienert et al., 2005). 


\section{Appendix A}

\section{A1 Vertical flow}

In previous versions of the SpongeBOB model, the fluid flow was calculated explicitly, at each time step, as a function of $P_{\text {excess }}$ at the beginning of the time step. Numerical stability motivated a modification of the vertical flow to an implicit numerical scheme, which finds, by iteration, an internally consistent array of vertical flow velocities and resulting $P_{\text {excess }}$ values from a time point at the end of the time step. Ocean and atmosphere models often use this methodology for vertical flow. A benefit of this change is stability in the vertical flow field, reducing numerical noise that can cause trouble with other aspects of the model, such as ice formation. Implicit schemes can be more efficient computationally, but in this case just the stability, and not the execution time, is improved by the implicit method.

Note that the flow scheme in its formulation is entirely elastic, whereas in reality, pore fluid excluded by the pressure of a sediment column above sea level, for example, where it is uncompensated for by buoyancy in seawater, should remain excluded when sea level rises again, like toothpaste from the tube. However, my attempts to embed this plastic behavior into an implicit solver failed to converge.

\section{A2 Ice formation}

The ice content in a grid cell relaxes toward equilibrium, quickly enough to approximate an equilibrium state through the slow temperature evolution in the model (which neglects a seasonal cycle at the surface) but slowly enough to avoid instabilities with other components of the model such as fluid flow and methane hydrate formation. A limiter in the code prevents more than $99 \%$ of the fluid in a grid cell from freezing, but the thermodynamic equilibrium salinity is used to calculate, for example, the stability of methane hydrate, to prevent the numerical limiter from affecting the thermodynamic availability of water to drive chemical reactions.

\section{A3 Thermodynamics of ice and hydrate}

When the system consists only of ice and fluid phases, the equilibrium salinity $S_{\text {eq }}$ increases with decreasing temperature below freezing (Fig. A1a, left). Above the melting temperature, ice is unstable, as indicated by the nonzero values of the disequilibrium temperature, $\Delta T_{\mathrm{eq}}$, ice $=T-T_{\mathrm{eq}}$, ice, in contours, even in zero-salinity water (right). For a system consisting of only the hydrate and fluid phases (assuming that gas saturation for methane and ice formation is disallowed; Fig. A1b), the behavior is similar but with an added pressure dependence due to the compressibility of the gas phase.

When both solid phases are allowed, the overall equilibrium salinity will be whichever is higher between $S_{\text {eq, ice }}$ and

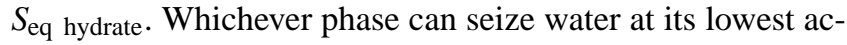
tivity (highest salinity) will be the stable phase. The salinity
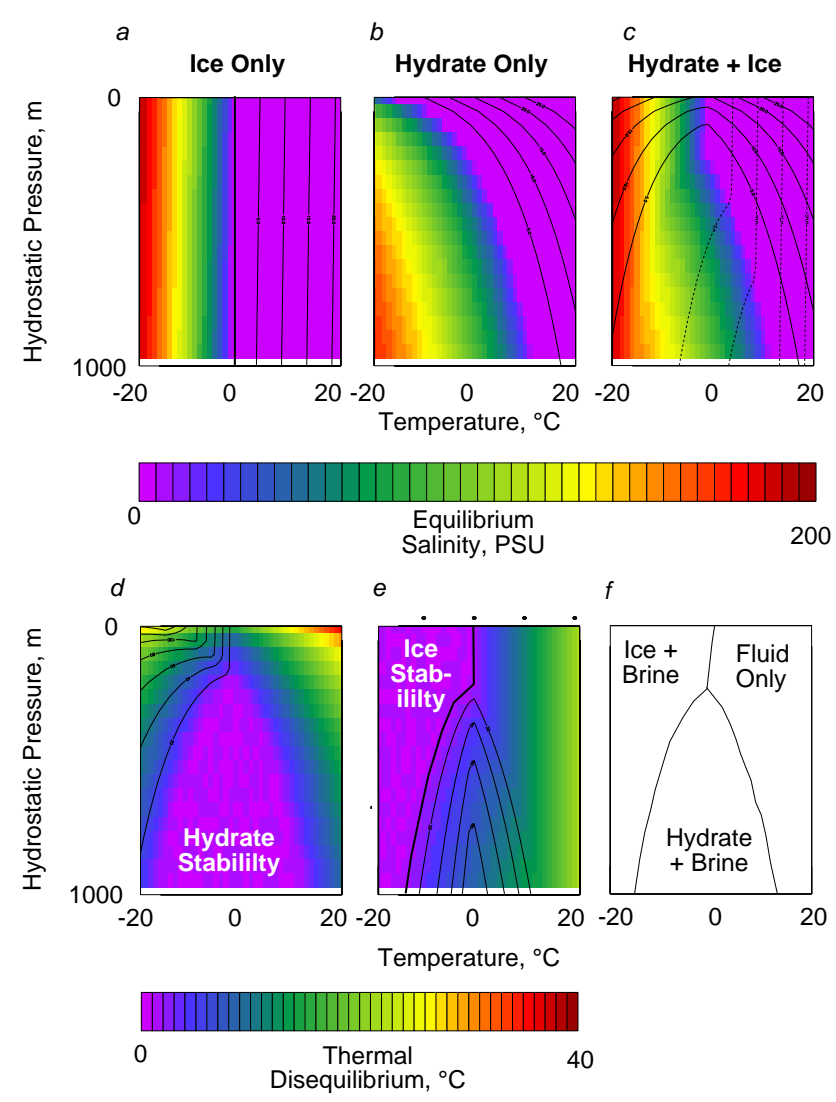

Figure A1. Thermodynamics of hydrate and ice. (Top) Colors are salinities, which range from fresh if there is no solid phase to saltier as the freezing point depression of the solid phase follows the in situ temperature. Contours indicate the extent of thermal disequilibrium, $\Delta T_{\mathrm{eq}}=T-T_{\mathrm{eq}}$. Panel (a) shows the thermodynamics for the system of ice and fluid. Panel (b) considers hydrate and fluid phases, excluding ice formation and assuming equilibrium with methane gas. Panel (c) shows combined ice + hydrate + fluid system, where the salinity is controlled by the most stable solid phase. Solid con-

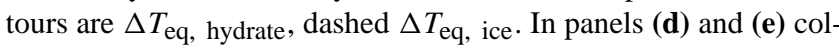
ors are $\Delta T_{\text {eq }}$, where 0 (purple) indicates stability, and contours are the excess salinity relative to a solid phase, e.g., $S_{\max }-S_{\text {eq, hydrate }}$ in (d) for hydrate and (e) for ice. Panel (f) shows a phase diagram for the ice + hydrate + brine system. Hydrate is excluded from the ice phase space by the high salinity of the brine. Ice is ideally also excluded from part of the hydrate stability zone by a similar mechanism, but this would only happen in nature under conditions of unlimited methane availability. Thus, it is easier to envision coexistence of hydrate and ice within the hydrate stability zone, under conditions of limited methane availability, than it is to imagine hydrate in the permafrost zone, where ice has no impediment to formation.

of the brine excluded from that phase will be too high to permit the existence of the other solid phase at that temperature. The contours show $\Delta T_{\mathrm{eq}}$ for hydrate (solid) and ice (dashed), which are also plotted in color in Fig. Ald and e. This is illustrated in Fig. A1d, in colors of $\Delta T_{\text {eq, hydrate }}$ and contours of the excess salinity relative to hydrate equilibrium, $S_{\max }$ 


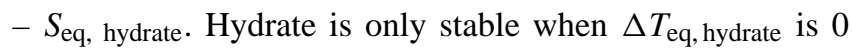
(purple color).

Under permafrost conditions of low pressure and low temperature (upper left corner), $\Delta T_{\mathrm{eq}}$, hydrate is greater than 0 , indicating that hydrate is unstable and coinciding with the salinity forcing from the ice (in overlain contours). A similar exclusion of ice in part of the hydrate stability zone is seen in Fig. A1e, but this would only happen in nature in conditions of unlimited methane. The resulting phase diagram for ice and methane hydrate is shown in Fig. A1f. Hydrate stability is suppressed in the permafrost zone by this thermodynamic mechanism.

There is an analogous exclusion of ice from part of the methane hydrate stability zone, but this assumes unlimited methane; if the dissolved methane concentration is less than gas saturation, both solid phases can coexist. In the permafrost zone, the dissolved methane concentration cannot exceed solubility with gas saturation, so the exclusion of methane hydrate from thermodynamic stability is inescapable.

\section{A4 Construction of the prefreshened sediment column}

If sea level falls, exposing the sediment column to the atmosphere for the first time, there is a pressure head gradient extending throughout the sediment column, provoking lateral flow at all depths. As the pore fluid at the surface is replaced by fresh runoff, the lighter density of that fluid tends to diminish the pressure head gradient in the deeper sediment column. The deeper pressure gradient and flow approach 0 as the freshwater lens in the outcropping region approaches an isostatic equilibrium condition known as the Ghyben-Herzberg relation (Moore et al., 2011), in which each meter elevation of the water table is compensated for by about $40 \mathrm{~m}$ of freshwater below sea level, determined by the difference in densities of fresh and salt water.

To create this condition within the model, two simulations are presented in which sea level was decreased by 30 and $120 \mathrm{~m}$, respectively, and held there for millions of years (Fig. A2). The $30 \mathrm{~m}$ drop experiment produced land outcrop in about $1 / 4$ of the model domain, with the predicted equilibrium Ghyben-Herzberg halocline reaching about $1200 \mathrm{~m}$ maximum depth. The model salinity relaxes into close agreement with the predicted halocline, lending support to the model formulation for density, pressure head, and fluid flow. As time progresses further, the outcropping land surface subsides (there is no land deposition in this scenario), until it drops below the new lowered sea level value after about 2.5 Myr. The hydrological pumping generates a low-methane plume that also persists for millions of years in the model (Fig. A3).

Variants of this experiment were done with differing values of the lateral distance to drainage canyons in the model, which provide a pathway for fluid loss in sediments above sea level. When a hypothetical canyon is located $10 \mathrm{~km}$ from the
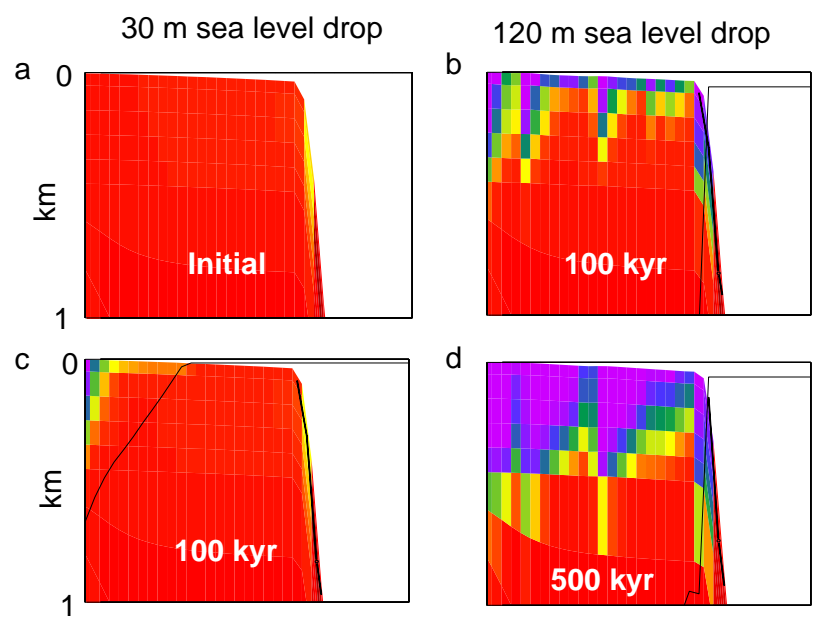

d
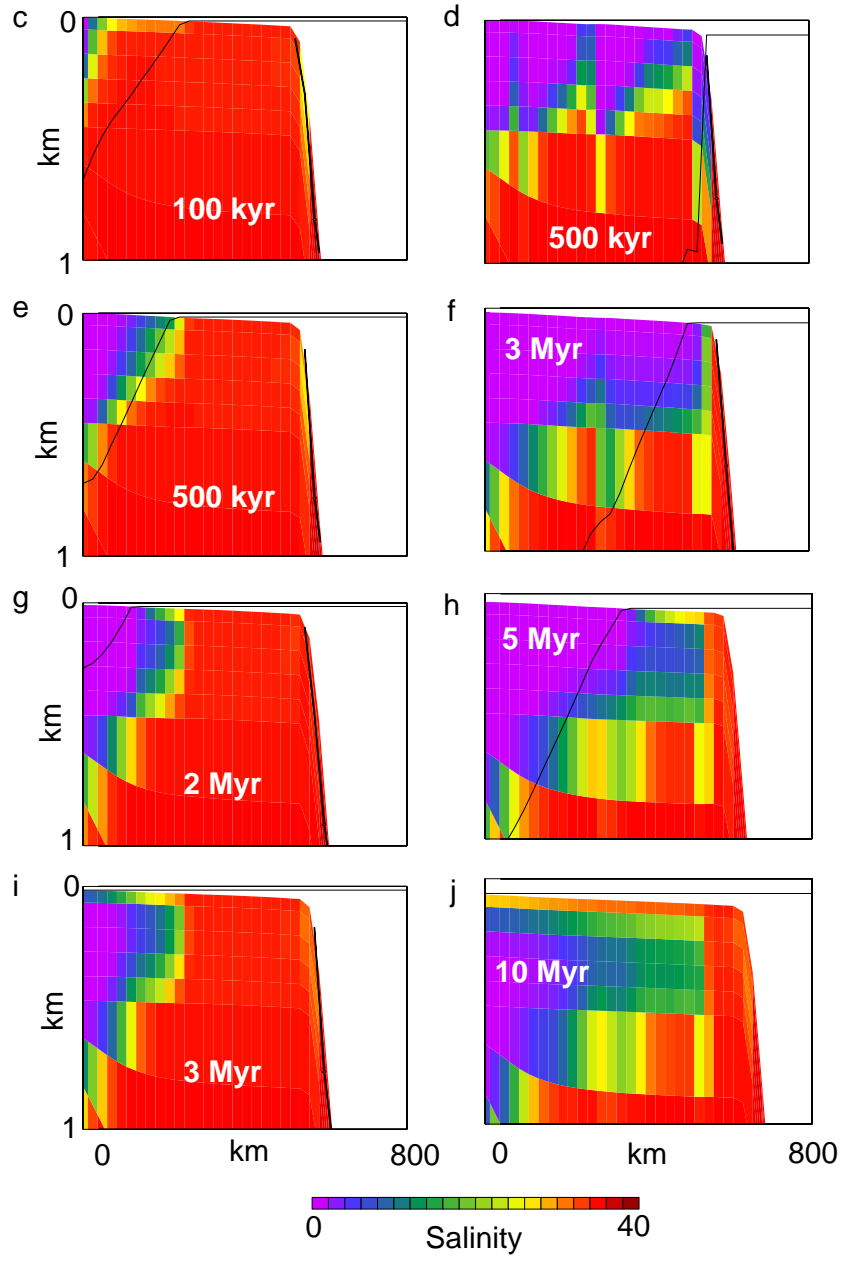

Figure A2. Freshening the sediment column by hydrological groundwater flushing. Color indicates salinity. Solid black line represents sea level in the ocean (white space), and the equilibrium Ghyben-Herzberg fresh-salty boundary given the pressure head. Left side: results of dropping sea level by $30 \mathrm{~m}$ and holding it there. A freshwater lens forms and strives to reach Ghyben-Herzberg equilibrium as the sediment column subsides, where atmospheric exposure decreases its buoyancy and stops sediment accumulation. After the sediment column subsides beneath the still-lowered sea level, the freshwater lens remains for millions of years. A movie can be seen at http://geosci.uchicago.edu/ archer/spongebob_arctic/ supp_fig2a.movie.gif. Right side: result of dropping sea level by $120 \mathrm{~m}$ and holding it there forever. Movie at http://geosci.uchicago. edu/ archer/spongebob_arctic/supp_fig2b.movie.gif. 


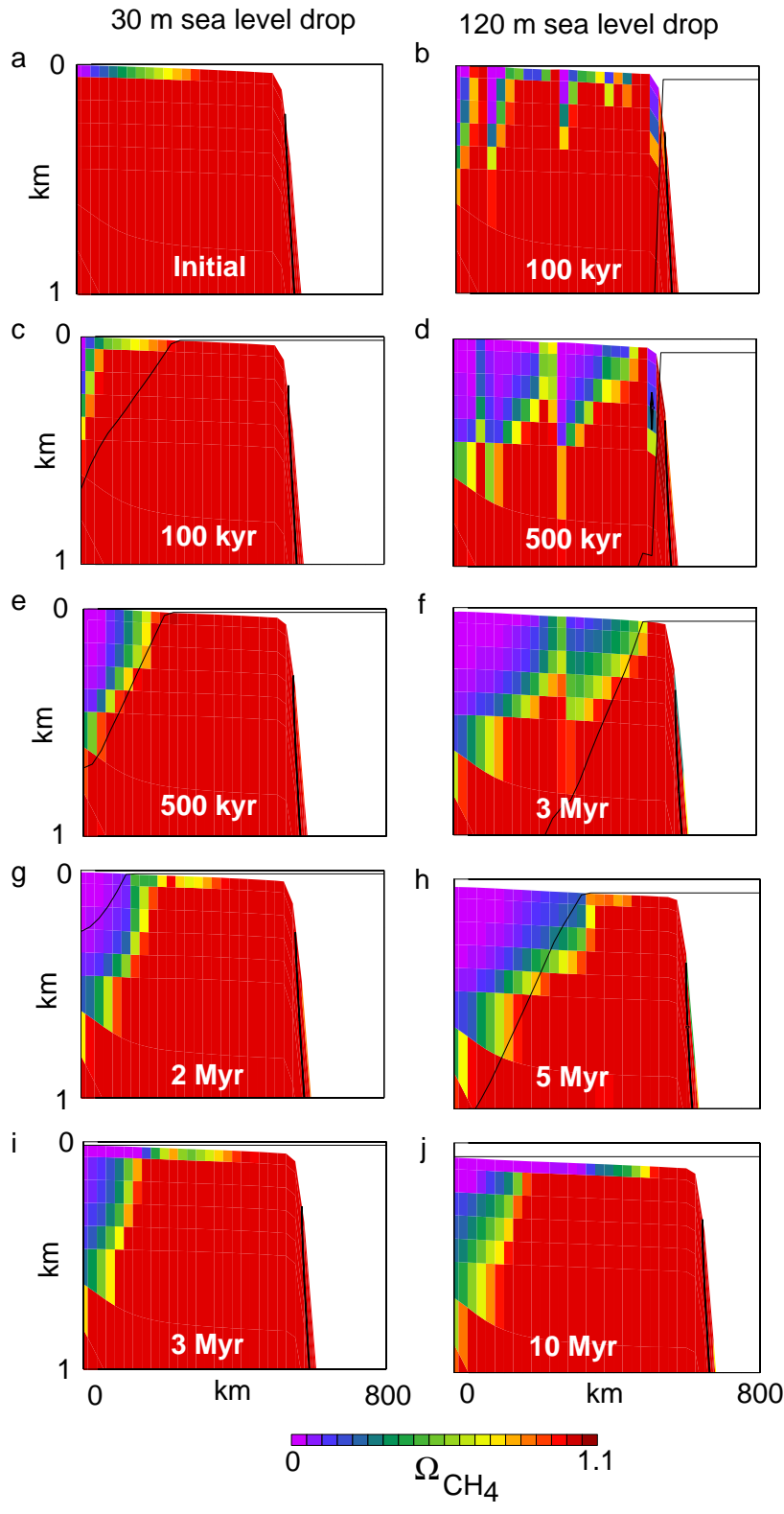

Figure A3. Dissolved methane impact by hydrological freshening of the sediment column as described in Fig. A2. $\Omega=\mathrm{CH}_{4} / \mathrm{CH}_{4}$ (sat). Movies can be seen at http://geosci.uchicago.edu/ archer/ spongebob_arctic/supp_fig3a.movie.gif and http://geosci.uchicago. edu/ archer/spongebob_arctic/supp_fig3b.movie.gif.

SpongeBOB slab, the model salinity approaches equilibrium on an $e$-folding timescale of about $400 \mathrm{kyr}$ (Fig. A4). When the canyon is $100 \mathrm{~km}$ distant or nonexistent, the equilibration timescale is about $600 \mathrm{kyr}$. Based on the idea that canyons are of the order of $100 \mathrm{~km}$ in length should be about $100 \mathrm{~km}$ apart, the base simulation in this paper assumes canyon spacing of $100 \mathrm{~km}$.

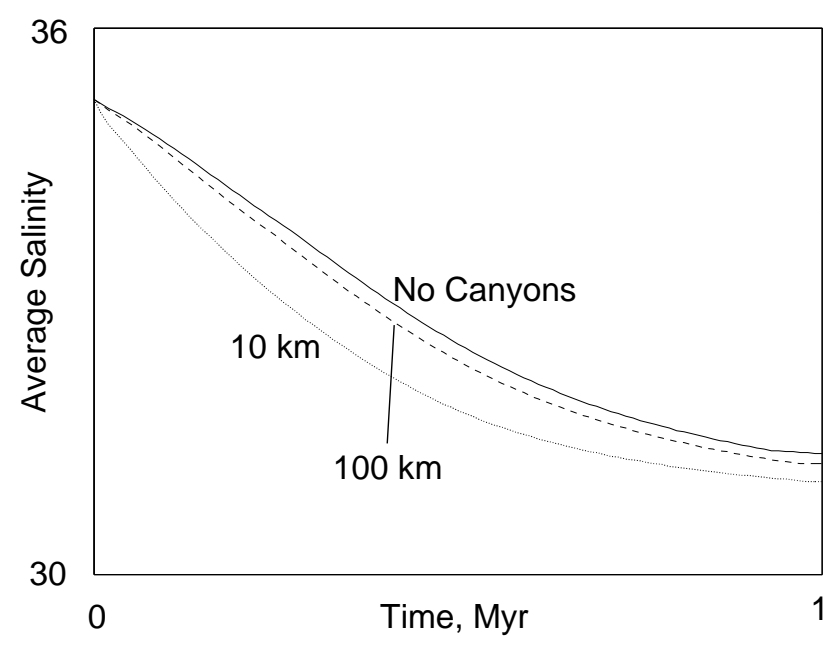

Figure A4. Timescale of depleting the salinity of the continental shelf sediment column after an instantaneous sea level drop of $30 \mathrm{~m}$. The effect of lateral canyons is to provide a pathway for saline fluid to be replaced by fresh groundwater in sediments above sea level. If the lateral canyon spacing is $10 \mathrm{~km}$, they can have a significant impact on the time constant for groundwater flushing. A more conservative $100 \mathrm{~km}$ canyon is adopted for the rest of the simulations.

When sea level is lowered by $120 \mathrm{~m}$, the sequence of events is similar, except that the pressure head is so high that to satisfy the Ghyben-Herzberg relation would require fresh pore waters at many kilometers depth, even deeper than bedrock on the "continental" side of the model domain. Because of the low permeability of the deepest sediment column, the freshwater-pumping groundwater mechanism is unable to reach these deepest pore waters, which therefore remain salty. The timescale for establishing a significant freshening of the upper kilometer of the sediment column is still on the order of 100-500 kyr, and the subsequent subsidence time of the sediment column in the model, until it drops below the new lowered sea level, is about $10 \mathrm{Myr}$. In both cases, subsidence of the exposed sediment column prevents the sediment surface in the model from remaining above sea level indefinitely (without land deposition). 


\section{The Supplement related to this article is available online at doi:10.5194/bg-12-2953-2015-supplement.}

Acknowledgements. This paper benefited from constructive reviews by Dmitri Nicolsky and two anonymous reviewers, comments contributed by Natalia Shakhova, Igor Semiletov, and Vladimir Tumskoy, and the efforts of the editor, Laurent Bopp.

Edited by: L. Bopp

\section{References}

Archer, D. and Brovkin V.: The millennial lifetime of fossil fuel $\mathrm{CO}_{2}$, Climatic Change, 90, 283-297, 2008.

Archer, D. E., Buffett, B. A., and McGuire, P. C.: A twodimensional model of the passive coastal margin deep sedimentary carbon and methane cycles, Biogeosciences, 9, 2859-2878, doi:10.5194/bg-9-2859-2012, 2012.

Archer, D. E., Eby, M., Brovkin, V., Ridgewell, A. J., Cao, L., Mikolajewicz, U., Caldeira, K., Matsueda, H., Munhoven, G., Montenegro, A., and Tokos, K.: Atmospheric lifetime of fossil fuel carbon dioxide, Ann. Rev. Earth Planet Sci., 37, 117-34, 2009.

Cramer, B. and Franke, D.: Indications for an active petroleum system in the Laptev Sea, NE Siberia, J. Petrol. Geol., 28, 369-383, 2005.

Dutta, K., Schuur, E. A. G., Neff, J. C., and Zimov S. A.:, Potential carbon release from permafrost soils of Northeastern Siberia, Glob. Change Biol., 12, 2336-2351, 2006.

Gavrilov, A. V., Romanovskii, X. N., Romanovsky, V. E., Hubberten, H. W., and Tumskoy, V. E.: Reconstruction of ice complex remnants on the eastern Siberian Arctic Shelf, Permafrost Periglac., 14, 187-198, 2003.

Gentz, T., Damm, E., von Deimling, J. S., Mau, S., McGinnis, D. F., and Schluter, M.: A water column study of methane around gas flares located at the West Spitsbergen continental margin, Continent. Shelf Res., 72, 107-118, 2014.

Hill, J. C., Driscoll, N. W., Weissel, J. K., and Goff, J. A.: Large-scale elongated gas blowouts along the US Atlantic margin, J. Geophys. Res.-Solid Earth, 109, B09101, doi:10.1029/2004JB002969, 2004.

Hunt, J. M.: Petroleum Geochemistry and Geology, 743 pp., Freeman, New York, 1995.

Khvorostyanov, D. V., Ciais, P., Krinner, G., Zimov, S. A., Corradi, C., and Guggenberger, G.: Vulnerability of permafrost carbon to global warming. Part II: sensitivity of permafrost carbon stock to global warming, Tellus B, 60, 265-275, 2008a.

Khvorostyanov, D. V., Krinner, G., Ciais, P., Heimann, M., and Zimov, S. A.: Vulnerability of permafrost carbon to global warming, Part I: model description and role of heat generated by organic matter decomposition, Tellus B, 60, 250-264, $2008 \mathrm{~b}$.

Kooi, H., Groen, J., and Leijnse, A.: Modes of seawater intrusion during transgressions, Water Resour. Res., 36, 3581-3589, 2000.

Kort, E. A., Wofsy, S. C., Daube, B. C., Diao, M., Elkins, J. W., Gao, R. S., Hintsa, E. J., Hurst, D. F., Jimenez, R., Moore, F. L., Spackman, J. R. and Zondlo, M. A.: Atmospheric observations of Arctic Ocean methane emissions up to 82 degrees north, Nat. Geosci., 5, 318-321, 2012.

Lu, C. and Werner, A. D.: Timescales of seawater intrusion and retreat, Adv. Water Resour., 59, 39-51, 2013.

Martin, P. A., Lea, D. W., Rosenthal, Y., Shackleton, N. J., Sarnthein, M., and Papenfuss, T.: Quaternary deep sea temperature histories derived from benthic foraminiferal $\mathrm{Mg} / \mathrm{Ca}$, Earth Planet. Sci. Lett., 198, 193-209, 2002.

Mienert, J., Vanneste, M., Bunz, S., Andreassen, K., Haflidason, H. and Sejrup, H. P.: Ocean warming and gas hydrate stability on the mid-Norwegian margin at the Storegga Slide, Mar. Petrol.Geol., 22, 233-244, 2005.

Moore, W. S., Carlson, C. A., and Giovannoni, S. J.: The Effect of Submarine Groundwater Discharge on the Ocean, Annual Review of Marine Science, 2, 59-88, 2011.

Nicolsky, D. and Shakhova, N.: Modeling sub-sea permafrost in the East Siberian Arctic Shelf: the Dmitry Laptev Strait, Environ. Res. Lett., 5, 015006, doi:10.1088/1748-9326/5/1/015006, 2010.

Nicolsky, D. J., Romanovsky, V. E., Romanovskii, N. N., Kholodov, A. L., Shakhova, N. E., and Semiletov, I. P.: Modeling subsea permafrost in the East Siberian Arctic Shelf: The Laptev Sea region, J. Geophys. Res.-Earth Surface, 117, F03028, doi:10.1029/2012JF002358, 2012.

Portnov, A., Smith, A. J., Mienert, J., Cherkashov, G., Rekant, P., Semenov, P., Serov, P., and Vanshtein, B.: Offshore permafrost decay and massive seabed methane escape in water depths $>$ $20 \mathrm{~m}$ at the South Kara Sea shelf, Geophys. Res. Lett., 40, 3962 3967, 2013.

Post, V. E. A., Groen, J., Kooi, H., Person, M., Ge, S. M., and Edmunds, W. M.: Offshore fresh groundwater reserves as a global phenomenon, Nature, 504, 71-78, 2013.

Reagan, M. T.: Dynamic response of oceanic hydrate deposits to ocean temperature change, J. Geophys. Res.-Oceans, 113, C12023, doi:10.1029/2008JC004938, 2008.

Reagan, M. T. and Moridis, G. J.: Large-scale simulation of methane hydrate dissociation along the West Spitsbergen Margin, Geophys. Res. Lett., 36, L23612, doi:10.1029/2009GL041332, 2009.

Reagan, M. T., Moridis, G. J., Elliott, S. M., and Maltrud, M.: Contribution of oceanic gas hydrate dissociation to the formation of Arctic Ocean methane plumes, J. Geophys. Res.-Oceans, 116, C09014, doi:10.1029/2011JC007189, 2011.

Riedel, M., Spence, G. D., Chapman, N. R., and Hyndman, R. D.: Seismic investigations of a vent field associated with gas hydrates, offshore Vancouver Island, J. Geophys. Res.-Solid Earth, 107, 2200, doi:10.1029/2001JB000269, 2002.

Romanovskii, N. N. and Hubberten, H. W.: Results of permafrost modelling of the lowlands and shelf of the Laptev Sea region, Russia, Permafrost Perigla., 12, 191-202, 2001.

Romanovskii, N. N., Hubberten, H. W., Gavrilov, A., Tumskoy, V. E., and Kholodov, A. L.: Permafrost of the east Siberian Arctic shelf and coastal lowlands, Quaternary Sci. Revi., 23, 13591369, 2004.

Romanovskii, N. N., Hubberten, H. W., Gavrilov, A. V., Eliseeva, A. A., and Tipenko, G. S.: Offshore permafrost and gas hydrate stability zone on the shelf of East Siberian Seas, Geo-Marine Lett., 25, 167-182, 2005.

Romanovskii, N. N., Hubberten, H. W., Gavrilov, A. V., Tumskoy, V. E., Tipenko, G. S., Grigoriev, M.N., and Siegert, C.: 
Thermokarst and land-ocean interactions, Laptev Sea Region, Russia, Permafrost Periglac., 11, 137-152, 2000.

Schuur, E. A. G., Bockheim, J.,Canadell, J. G., Euskirchen, E., Field, C. B., Goryachkin, S. V., Hagemann, S., Kuhry, P., Lafleur, P. M., Lee, H., Mazhitova, G., Nelson, F. E., Rinke, A., Romanovsky, V. E., Shiklomanov, N., Tarnocai, C., Venevsky, S., Vogel, J. G., and Zimov, S. A.: Vulnerability of permafrost carbon to climate change: Implications for the global carbon cycle, Bioscience, 58, 701-714, 2008.

Shakhova, N.: Geochemical and geophysical evidence of methane release over the East Siberian Arctic Shelf, J. Geophys. Res.Oceans, 115, C08007, doi:10.1029/2009JC005602, 2010.

Shakhova, N., Semiletov, I., Leifer, I., Sergienko, V., Salyuk, A., Kosmach, D., Chernykn, D., Stubb, C., Nicolsky, D., Tumskoy, V. E., and Gustafsson, O.: Ebullition and storm-induced methane release from the East Siberian Arctic shelf, Nat. Geosci., 7, 6470, doi:10.1038/NGEO2007, 2013.

Shakhova, N., Semiletov, I., and Panteleev, G.: The distribution of methane on the Siberian Arctic shelves: Implications for the marine methane cycle, Geophys. Res. Lett. 32, L09601, doi:10.1029/2005GL022751, 2005.

Shakhova, N., Semiletov, I., Salyuk, A., Yusupov, V., Kosmach, D., and Gustafsson, O.: Extensive Methane Venting to the Atmosphere from Sediments of the East Siberian Arctic Shelf, Science, 327, 1246-1250, 2010a.

Shakhova, N. E., Alekseev, V. A., and Semiletov, I. P.: Predicted methane emission on the East Siberian shelf, Doklady Earth Sciences, 430, 190-193, 2010b.

Shakhova, N. E., Nicolsky, D. Y., and Semiletov, I. P.: Current state of subsea permafrost on the East Siberian Shelf: Tests of modeling results based on field observations, Doklady Earth Sciences, 429, 1518-1521, 2009.

Stein, R., and Fahl, K.: Holocene accumulation of organic carbon at the Laptev Sea continental margin (Arctic Ocean): sources, pathways, and sinks, Geo-Mar. Lett., 20, 27-36, 2000.
Stouffer, R. J. and Manabe, S.: Equilibrium response of thermohaline circulation to large changes in atmospheric $\mathrm{CO}_{2}$ concentration, Clim. Dynamics, 20, 759-773, 2003.

Taylor, A. E., Dallimore, S. R., and Outcalt, S. I.: Late quaternary history of the Mackenzie-Beaufort region, Arctic Canada, from modelling of permafrost temperatures 1, The onshore offshore transition, Can. J. Earth Sci., 33, 52-61, 1996.

Valentine, D. L., Blanton, D. C., Reeburgh, W. S., and Kastner, M.: Water column methane oxidation adjacent to an area of active hydrate dissociation, Eel River Basin, Geochim. Cosmochim. Ac., 65, 2633-2640, 2001.

Verrjuit, A.: A note on the Ghyben-Herzberg formula, Bull. Int. Assoc. Sci. Hydrology, 13, 43-46, 1968.

Walter, K. M., Zimov, S. A., Chanton, J. P., Verbyla, D., and Chapin, F. S.: Methane bubbling from Siberian thaw lakes as a positive feedback to climate warming, Nature, 443, 71-75, 2006.

Watson, T. A., Werner, A. D., and Simmons, C. T.: Transience of seawater intrusion in response to sea level rise, Water Resour. Res., 40, W12533, doi:10.1029/2010WR009564, 2010.

Westbrook, G. K., Thatcher, K. E., Rohling, E. J., Piotrowski, A. M., Paelike, H., Osborne, A. H., Nisbet, E. G., Minshull, T. A., Lanoiselle, M., James, R. H., Huehnerbach, V., Green, D., Fisher, R. E., Crocker, A. J., Chabert, A., Bolton, C., BeszczynskaMoeller, A., Berndt, C., and Aquilina, A.: Escape of methane gas from the seabed along the West Spitsbergen continental margin, Geophys. Res. Lett., 36, L15608, doi:10.1029/2009GL039191, 2009.

Zimov, S. A., Davydov, S. P., Zimova, G. M., Davydova, A. I., Schuur, E. A. G., Dutta, K., and Chapin, F. S., III: Permafrost carbon: Stock and decomposability of a globally significant carbon pool, Geophys. Res. Lett., 33, L20502, doi:10.1029/2006GL027484, 2006. 